\title{
"AWAKENING THE SLEEPING GIANT:" INDIA AND FOREIGN DIRECT INVESTMENT IN THE $21^{\text {ST }}$ CENTURY
}

\author{
Mark B. Baker
}

\section{THE SLEEPING GIANT}

"India is the greatest democracy in the world. The government here is like an old elephant: vast, but slow and avoidable. Clever people can keep from being stepped on."1

Imagine, a great leviathan nation-state, larger in size and population than its neighbors and a member of a class of two, ${ }^{2}$ one of whom is historically and politically outside the main stream of the capitalist world. We are speaking of course about India, land of many cultures and languages and an anomaly of the highest order.

Like a modern day Rip Van Winkle, India is in its own way awakening from a long and somewhat unfulfilling time of its existence. ${ }^{3}$ Unlike the "old man of the mountain," however, it is not the dying echo of bowling pins being struck that awakens India, but rather the "sounds of money" being made as a result of the freewheeling world of foreign trade and investment in the twentyfirst century. ${ }^{4}$ The siren song of development is ringing all about the less developed world, and to miss its call is to allow nations and its citizens to languish in perpetual poverty.

This paper attempts to introduce the reader to the reality of India's past and future and the role of law in bringing the giant closer to its potential.

\section{INDIA'S POTENTIAL IN ATTRACTING FOREIGN DIRECT INVESTMENT}

India has the potential to become one of the most dominant economies in the world, yet its economic progress since gaining its independence in 1947 has generally been masked by its perception as an impoverished country, as has its

* Associate Professor of International Business Law, McCombs School, University of Texas at Austin; B.B.A., University of Miami, 1968; J.D., Southem Methodist University, 1974. The author gratefully acknowledges the efforts of Ms. Carolyn DeClue, B.B.A., University of Texas at Austin, 2000; J.D. Candidate, 2005, University of Texas at Austin.

1. Mark Jenkins, The Ghost Road, OuTsIDE, October 2003, at http://outside.away.com/ outside/features/200310/200310_burma_1.html (last visited Mar. 22, 2005).

2. The other, of course, is the People's Republic of China.

3. See generally WASHINGTON IRVING, RIP VAN WINKLE (1907), available at http://www.classicallibrary.org/irving/rip/ (last visited Feb. 14, 2005).

4. Id. 
vast potential for further development. ${ }^{5}$ It has the fourth largest economy in the world and the second largest Gross Domestic Product (GDP) among developing countries based on purchasing power and a large and growing market. ${ }^{6}$ India has the second largest population in the world, behind only China, with over a billion people. ${ }^{7}$ While only occupying about $2.4 \%$ of the world's land mass, the country supports almost $16 \%$ of the global population. ${ }^{8}$ India's consumer market has been rapidly growing, and now stands at approximately 300 million people with increasing purchasing power. ${ }^{9}$ This market is growing at an estimated $8 \%$ per annum, and the demand for several consumer products is growing at over $12 \%$ per annum. ${ }^{10}$ With its strategic location, India has access to the large South Asian market, and is a favorable location for a multinational company to expand throughout Asia. ${ }^{11}$ These benefits have been further complimented by the government's progressive liberalization of foreign direct

5. Le-Nhung McLeland \& Herbert O'Toole, Patent Systems in Less Developed Countries: The Case of India and the Andean Pact Countries, 2 J.L. \& TECH. 229, 232 (1987).

6. Ministry of EXTERNAL AfFAIRS (INDIA), INV. \& TrADE Promotion Div., BRIEF FOR Promotion of FOREIGN INVESTMENT \& BUSINESS, at http://www.embindia.org/Articulos/ Investbrief0804.htm (Aug. 4, 2004) (last visited Mar. 22, 2005).

7. As of 0:00 GMT, March 1, 2001, India had a total of 1,027,015,247 people. It is the second country, following only China, to cross the one billion population mark. OFFICE OF THE Register Gen., Census of India 2001, Provisional Population Totals: India (2001), http://www.censusindia.net/results/resultsmain.html. See generally Xizhe Peng, Population Policy and Program in China: Challenge and Prospective, 35 TEX. INT'L L.J. 51 , 54 (2000). In an effort to improve the quality of life of the Chinese people and to create the groundwork for social and economic development, China has adopted a population policy designed to reduce its population to a sustainable level. Id. China's government feels that government intervention is essential in slowing the population growth rate and maintaining the optimal population size.

The basic principles of the current population policy in China include the promotion of late marriages and deferred child birth, the urging of people to have fewer health births, the promotion of the practice of one birth per couple, and the encouragement of a longer birth spacing for families who may have practical difficulties if they were only to have one child.

Id. India, on the other hand, uses different approaches to deal with its population growth. First, they legalized abortion up to twenty weeks of pregnancy under the Medical Termination of Pregnancy Act of 1972 (MTP). Andrea Krugman, Being Female Can be Fatal: An Examination of India's Ban on Pre-Natal Gender Testing, 6 CARDOZO J. INT'L \& COMP. L. 215, 216-217 (1998). They also try to reduce the population growth rate by educating women and promoting family planning with television and billboard ads. Additionally, the government has tried to convince couples to abort female children. Id. Since there is pressure to have only one or two children, many Indian women go through prenatal gender testing so that the family can ensure their one or two children will be male. Due to negative social consequences, such as discrimination resulting from prenatal screening, this test was banned in 1994 with the Pre-Natal Diagnostic Techniques (Regulation and Prevention of Misuse) Act. Id.

8. Population of India: Studies and Research on India's Population, INDIAN CHILD, at http://www.indianchild.com/population_of_india.htm (n.d.) (last visited Mar. 22, 2005).

9. Indian Inv. Ctr., India's Investment Climate: Why Invest in India, at http://iic.nic.in/ iic2 a.htm (2000) (last visited Mar. 22, 2005) [hereinafter Indian Inv. Ctr.].

10. Id.

11. Id. 
investment (FDI) policy. ${ }^{12}$ One may contend that at present, India has recognized that FDI is an important driver for economic growth and has gone to great lengths to clarify and simplify its investment procedures. However, despite its vast potential, India has failed to achieve a reputation, nor reach its potential, as an attractive destination for FDI. This article attempts to bring a semblance of order and understanding to the inherently complex and somewhat contradictory use of law to enhance FDI. ${ }^{13}$

12. Lakshmi Chand, Foreward to SECRETARIAT FOR INDUS. ASSISTANCE, INDIAN MINISTRY OF COMMERCE AND INDUS., MANUAL ON FOREIGN DIRECT INVESTMENT IN INDIA - POLICY AND Procedures 3 (2004), http://64.233.167.104/search?q=cache:JQBwuXsRMXcJ:www. embkoreain.org/sub7/FDIManual_Mar2k4_Eng.pdf+\%22MANUAL+ON+FOREIGN+DIRECT + +INVESTMENT+IN+INDIA $\% 22$ + $\% 22$ POLICY+\% $\%$ +PROCEDURES $\% 22+\& \mathrm{hl}=\mathrm{en}$.

13. Like so many of the other issues shrouded in controversy, the matter at hand is not one of first impression. Indeed, in an article favored by this author, Ewell E. Murphy, Esq., has crafted a marvelous "fairy tale" that is replicated herein. A reading of the piece clearly illustrates the constant pressures that the less-developed world faces when opening its borders to FDI.

Once upon a time, in a country far away, there lived a King. His only wish was the contentment of his people-the Plumed-Serpent People, they were called, in echo of a legend of their race. Each dusk the King would pace the garden of his castle-hill above the volcano-guarded lake, considering how he might defend his people from the Giant. For in the North from sea to sea marched with the King's domain the vaster-yet dominion of a Giant. Already had the Giant seized [for more].

Pondering this shadow on his subjects' happiness, the King one evening summoned to his garden Lord Porfirio, tall, fearless warrior from the South, and asked him how they should attack the Giant.

'The best attack,' Porfirio advised, 'is no attack at all. Admit the Giant People to our land. We've many skills to gain [from] them, and gold. As they wax docile, so shall we grow strong. We will rise up one day, and cast them out.'

And so the Giant People came. Their skills, indeed, they taught, but haughtily, and without gaiety or grace. The gold they brought seemed nothing to the wealth they wrung from their adopted soil. At last Plumed-Serpent Land rose up and cast them out, and Lord Porfirio as well.

That does not end the tale. In time the Giant Folk returned, not to seize land, but worse, to dominate in devious ways the crafts and harvests of the realm. Once more the people murmured and the King paced sadly in the garden of his castlehill. At length he called Lord Louis, clever baron of the West, and bade him solve the problem of the Giant.

'We must construct a Wall,' the Baron said, 'too tall for Giant Folk to scale, with gates so low and narrow that their knights must leave both horse and lance behind and enter, if at all, as harmless peddler-men.'

And in a twinkling it was done: a mighty bulwark rose across Plumed-Serpent Land ... and for a time the Plumed-Serpent People dwelled content.

But not for long. Too soon Plumed-Serpent Land grew restive and the people murmured once again. One night a deputation of his liegemen gained an audience in the garden of the King: not mighty warriors of the South or clever barons of the West, but city knights and merchant guildsmen from the King's 


\section{INDUSTRIAL POLICY OF 1991}

Notwithstanding that stated above, India has made many great improvements over the last decade in achieving economic growth and poverty reduction. $^{14}$ The most significant advancement came in 1991 when India removed governmental obstacles and allowed its doors to open to foreign investment. ${ }^{15}$ The Industrial Policy of 1991 greatly enhanced the business climate in India and provided clarity to foreign businesses looking to invest in India. Prior to the implementation of this policy, foreign investment was allowed on a case-by-case basis. It was usually capped at $40 \%$ of the total equity capitalization, unless the investment included sophisticated technology that was unavailable in India, or the venture was predominately exportoriented. ${ }^{16}$ The new welcoming attitude of the government was reflected in the Industrial Policy, which liberalized the internal licensing requirements for businesses and retained only minimum procedural formalities. ${ }^{17}$ In the words of policy makers: "The industrial policy reforms have reduced the industrial licensing requirements, removed restrictions on investment and expansion, and facilitated easy access to foreign technology and foreign direct investment."18

own North, where the Plumed-Serpent People grow as strong as, and stronger than, the Giant's men. Lord Heron was their chief.

'Great King,' he said, 'we do not contradict the wisdom of the Wall. We cavil solely at the gates. They open only inward, and thus hinder our own exits with our goods. As for their height and beam, they block the taller lancemen of the Giant, admitting only puny squires. Our blades grow rusty and our sinews soft, for want of fight. How shall we master jousting in the world beyond the Wall, lacking fit sport at home?'

The King turned wordlessly away. They say he wanders wordless yet-when the night is clear and a full moon enchants the castle-hill, he can be seen pacing his garden, pondering the inconstancy of men and the perversity of walls.

Ewell E. Murphy, Jr., The Echeverrian Wall: Two Perspectives on Foreign Investment and Licensing in Mexico, 17 TEX. INT'L L.J. 135, 135-36 (1982).

14. Nicholas Stem, World Bank Group, Public Finance and Policy for Development: Challenges for India, Silver Jubilee Lecture (Jan. 10, 2002), http://econ.worldbank.org/files/ 11413 Nick_Stern_NIPFP_revised_Feb_28-02.pdf (last visited Mar. 22, 2005).

15. Nicky Jatana, Did Whirlpool Make its Mark in India?: N.R. Dongre v. Whirlpool Corp., 10 TRANSNAT'L LAw. 331, 336 (1997). The new government attitude towards FDI is reflected in the 1991 New Industrial Policy Statement, which specifically states that "[t]he government will therefore welcome foreign investment which is in the interest of the country's industrial development." MINISTRY OF INDUS., GOv'T. OF INDIA, STATEMENT ON INDUSTRIAL Policy (1991), http://siadipp.nic.in/publicat/nip0791.htm (last visited Mar. 31, 2005); see also PRICE WATERHOUSE, DOING BUSINESS IN INDIA 23 (1996). This was an attitude that many countries adopted as FDI was seen as more of a building block for developing countries, rather than a stumbling block that resulted in dependency on larger, developed countries. Id. India, however, was a latecomer in the adoption of this belief. Id.

16. Price Waterhouse, supra note 15 at 24.

17. TONY KHINDRIA, FOREIGN DIRECT INVESTMENT IN INDIA 18 (1997).

18. SECRETARIAT FOR INDUS. ASSISTANCE, INDIAN MINISTRY OF COMMERCE AND INDUS., MANuAl on Foreign Direct InVESTMENT IN INDIA-POLICY \& PROCEDURES 9 (2004), available at http://64.233.167.104/search?q=cache:JQBwuXsRMXcJ:www.embkoreain.org/sub7/FDI 
Under this policy, most investments can come in under the automatic route. ${ }^{19}$ There are also categories of investment that, while not listed as eligible for automatic approval, may be eligible as such if the investment falls within the foreign investment caps. ${ }^{20}$

Prior to 1998, however, nonresidents had to obtain prior approval pursuant to the terms of the Foreign Exchange Regulatory Act (FERA), even for investments eligible for automatic approval. ${ }^{21}$ This policy was further liberalized on January 20, 1998, when the Reserve Bank of India (RBI) changed the foregoing rule by allowing Indian companies to issue and export equity shares to foreign investors without prior approval. ${ }^{22}$ The automatic route now requires only that investors file the required documents, a declaration on Form FC, with the concerned Regional Office of the RBI within thirty days after the issue of the shares to foreign investors. ${ }^{23}$ The RBI gave this permission to Indian companies in an attempt to simplify FDI procedures under

Manual_Mar2k4_Eng.pdf+\%22MANUAL+ON+FOREIGN+DIRECT+INVESTMENT+IN+IN DIA $\% 22+\% 22$ POLLICY $+\% 26+$ PROCEDURES $\% 22+\&$ hl=en (last visited Mar. 31,2005 ) [hereinafter INDUSTRIAL POLICY].

19. All investments for FDI/Non Resident Indian (NRI)/Overseas Corporate Bodies (OCB) up to $100 \%$ fall under the automatic route except:

(i) All proposals that require an Industrial License which includes:

(a) the item requiring an Industrial License under the Industries (Development \& Regulation) Act, 1951;

(b) foreign investment being more than 24 per cent in the equity capital of units manufacturing items reserved for the small scale industries; and

(c) all items which require an Industrial License in terms of the locational policy notified by Government under the New Industrial Policy of 1991.

(ii) All proposals in which the foreign collaborator has a previous/existing venture/tie up in India ... the modalities prescribed in Press Note No. 18 dated 14.12.1998 of 1998 Series, shall apply to such cases. ... However, this shall not apply to investment made by multilateral financial institutions such as ADB, IFC, CDC, DEG, etc. as also investment made in IT sector.

(iii) All proposals relating to acquisition of shares in an existing Indian company in favor of a foreign/NRI/OCB investor.

(iv) All proposals falling outside notified sectorial policy/caps or under sectors in which FDI is not permitted.

Id. at $13, \Upsilon 3.3$.

20. For example, investment in the development of petroleum products and pipelines up to $51 \%$ can go through the automatic approval process. Other examples include the development of small and medium sized oil up to $60 \%$, gas fields up to $51 \%$, and export enterprises with equity ownership between $51 \%$ and $100 \%$. Therefore, it is necessary to check with the RBI before one prepares an investment proposal to determine which sectors are currently eligible for automatic approval. TERRENCE F. MACLAREN, ECKSTROM'S LICENSING IN FOREIGN AND DOMESTIC OPERATIONS: JOINT VENTURES $§ 14.75$ (2003).

21. Id.

22. Id.

23. IndUSTRIAL POLICY, supra note 18 , at $15,73.12$; see KHINDRIA, supra note 17 , at 19 20. If a license is not required, the company only needs to file a memorandum with the Ministry of Industry. This memorandum is just an information sheet to keep the Ministry aware of developments in different industries. It is not an application for approval. Id. 
this "automatic route." 24 The prior licensing procedures represented many hurdles for foreign companies looking to do business in India. ${ }^{25}$ The Industrial Policy of 1991 was expected to avoid the red tape and corruption in the bureaucracy, and liberate Indian business. ${ }^{26}$ Now that the many restrictions have been lifted, companies with nonresident interests are placed on equal footing with Indian wholly-owned companies.

Other results of the 1991 policy included increasing income and improving the living standards of Indian residents over the last decade. The reform program has been the driving force behind accelerating economic growth, further declining poverty, and strengthening India's external position. ${ }^{27}$

\section{LABOR}

Another great benefit for businesses looking to invest in India, in addition to the liberal governmental policy, is the local employment population. Labor is the most dominant input for production in virtually every type of business. ${ }^{28}$ India is well positioned with regard to local market size and labor costs as it has one of "the largest domestic markets in the world and it has a large labor force available at relatively low cost." 29 These workers are also very well-educated, especially in the areas of engineering and science. ${ }^{30}$ "India's vast reservoir of knowledge resource - engineers, scientists, technicians, managers and skilled personnel, are among the best in the world. ${ }^{31}$ These resources continue to grow as the country welcomes approximately 200,000 new engineers per year. ${ }^{32}$ The labor population also continues to expand, as a number of the software developers and technology professionals are beginning to return to India from other countries to which they had emigrated for better career opportunities. In fact, in the last two years, about 35,000 software workers have returned to India. $^{33}$ As a result, in certain sectors, such as the production of computer

24. INDUSTRIAL POLICY, supra note 18 , at $15, \mathbb{7} 3.12$.

25. KHINDRIA, supra note 17, at 19.

26. Id.

27. Michael Carter, Opening Remarks, Workshop on Improving India's Investment Climate, available at http://nweb18.worldbank.org/SAR/sa.nsf/Attachments/mor/\$File/Mor.pdf (July 30, 2003) (last visited Mar. 22, 2005).

28. KHINDRIA, supra note 17 , at 217.

29. Dev. ECON. Group, WorLd BANK Group, IMPRoving THE INVESTMENT ClimATE IN INDIA 10 (2002), http://www.ifc.org/ifcext/economics.nsf/AttachmentsByTitle/lCindia_proof 3.pdf/\$FILE/IC-india_proof_3.pdf (last visited Mar. 22, 2005) [herinafter IMPROVING INVESTMENT ClimATE].

30. Id. at 10-11.

31. SINHA, supra note 6.

32. Bruce Einhorn, For India, a Shrinking IT Monster; Suddenly, Indians are realizing that their big edge in English skills and multinational investment should hold off China's software threat, BUSINESSWEEK ONLINE, July 1, 2003, at http://www.businessweek.com/ technology/content/july2003/tc2003071_2518_tc058.htm (last visited Mar. 22, 2003).

33. See generally Khozem Merchant, Economic Revival Could Lead to 'A Reverse Brain Drain': NON-RESIDENT INDIANS: Expatriate Bankers and Technologists are being Lured 
software, India offers investors a potentially higher rate of return than any other nation. ${ }^{34}$ In the language of one author, "India offers what in a competitive world may be the most valuable software of all: minds that have been permitted to be open, inquisitive and creative, and men and women who are fluent in the global language of business, English." ${ }^{35}$ In fact, India placed second in a poll of 400 executives who were asked to rank the labor forces of developing nations, ranking it ahead of China. ${ }^{36}$ Indeed, historically the Indian labor force

Back to India, FinANCIAL TIMES, Dec. 9, 2003. In the past, India's labor skills have been a detriment to the country, as many Indians have left to find work in more promising business climates. For example, Wall Street is filled with Indian financiers, and there are even more Indians who work in technology in the Silicon Valley. While India still has a large population of talented workers, this trend has resulted in a brain drain of over twenty million Non-Resident Indians (NRIs), depriving the country of many of its most promising workers and increasing the ratio of poor, uneducated workers. See id. As India's business climate begins to revive, this trend could reverse, providing India not only with the return of her skillful and educated NRIs, but also with the benefit of their experience of working in developed countries. These NRIs are a special group, as they are credible professionals, rather than the typical blue-collar immigrants India has experienced. These prodigal Indians could impart their knowledge to new businesses in the country, which in turn would increase the overall business climate exponentially. Not only would Indian businesses begin to flourish, but the increased business experience in the companies would influence foreign investors to increase contributions into the country. See id. Many experts feel that this could be the bridge needed between India's ideas and opportunities for investment and the business and political decision makers in the west. In fact, Rajit Gupta, an NRI and senior partner of the business consultancy, McKinsey, and former United States President Bill Clinton are involved with an investment fund that reflects this trend. Many business experts identify the NRIs as a tool used to influence western investors, as their success provides support for arguing the benefits of investing in India. Throughout the period that these NRIs have prospered in other countries, they have transferred little of this wealth back home. One of the reasons for low foreign investment numbers is that the NRIs did not support their home country in the past. See id. China, on the other hand, receives much of its foreign investment from expatriate Chinese. The return of the NRIs to India may be the payoff that Indian leaders have been unsuccessfully encouraging their natives to send back home. Indian leaders are starting to recognize the benefit of NRIs returning home, and in an effort to promote more, they have proposed the ability for Indians to have dual nationality if they live in one of seven countries, including the United States and the United Kingdom. Today, Indian technology companies have been heavily recruiting NRIs, as many of them have lost their jobs in the United States due to the bursting of the dot-com bubble. NRIs began assessing the Indian job market, and have reached the realization that coming back home to their families does not mean compromising their career as it used to. In fact, as many companies have begun outsourcing labor to India, NRIs have the opportunity to switch the country in which they work without having to change companies. Other NRIs have returned, not because they lost their jobs in America, but because they now see opportunities to do challenging work in India, rather than having to wait until opportunities arise in the United States. Despite the fact that many are still skeptical of corruption and regulatory burdens present throughout the bureaucracy of India, others see long term growth potential and opportunity, as India's technology and other skilled industries have started to gain prominence in the international arena. See id.

34. Ilyana Kuziemko \& Geoffrey Rapp, India's Wayward Children: Do Affirmative Action Laws Designed to Compensate India's Historically Disadvantaged Castes Explain Low Foreign Direct Investment by the Indian Diaspora?, 10 MinN. J. Global Trade 323, 337 (2001).

35. Birman Maharjan, India-China: The Elephant Versus the Tiger, in INVESTMENT GAME, (Inter Press Service, 1997), cited in Kuziemko, supra note 34, at 335.

36. Kuziemko, supra note 34 , at 335. 
has a generally favorable attitude toward foreign investment. ${ }^{37}$ This is generally because of a perception of a greater degree of professionalism in foreign business, and because of a lingering expectation of higher wages. ${ }^{38}$ The foreign company may, however, continue to employ foreign nationals, as " $[\mathrm{t}] \mathrm{he}$ government of India has not introduced any legislation to provide for the Indianization of employment." 39

Many multinational companies have taken advantage of the "personnel pool" which India possesses. The recent trend prevalent in business today, which was initiated by large companies such as Intel and Microsoft, is that of business-process outsourcing abroad. " $[\mathrm{H}]$ ardly a week goes by without another multinational announcing that it's opening or expanding an office in India so that low-salaried, high-skilled Indians can provide all sorts of backoffice support." ${ }^{, 40}$ Much of this support is in the form of call centers where Indians provide technical support and answer customer questions from half a world away. This is one area where India is confident that they can continually overpower China, largely because the Chinese do not speak English as well as the Indians. ${ }^{41}$ While China offers many other benefits for this type of outsourcing, the language barrier has deterred many companies from expanding there. ${ }^{42}$ Companies also have chosen India over other potential Asian outsourcing destinations due to its size. For example, countries such as the Philippines have a large population of talented workers but are nowhere near the size of India, where the talent pool is considered inexhaustible. ${ }^{43}$

The aforementioned trend has only just started, and is expected to gain momentum as more and more businesses recognize the economic benefits of outsourcing this type of labor. ${ }^{44}$ Even businesses that are reluctant to follow this trend will shortly be forced to do so in order to remain competitive with those already realizing great savings. ${ }^{45}$ Many investment professionals have

37. PRICE WATERHOUSE, supra note 15 , at 25.

38. Until recently, companies managed by foreign enterprises have paid higher than their local competitors and this perception remains prevalent in India. Id.

39. Id. at 104

40. Einhorn, supra note 32.

41. Id.

42. Id. For example, Adobe Systems considered opening a base in China, but decided against it as they saw language barriers. Adobe, however, has been consistently expanding its Indian operations due to the great quantity of English-speaking talent there. In fact, in late 2002 the company moved into a new $\$ 10$ million building in Noida, just outside of Dehi, which is the only building the company actually owns. In addition to the English speaking population, Adobe also chose India because of the availability of intelligent and talented manpower. Id.

43. Id.

44. "With the trend gaining momentum, more that $40 \%$ of U.S. companies will develop software or test it, offer tech support, or provide storage functions overseas by 2004, according to market consultancy Gartner." Olga Kharif, The Hidden Costs of IT Outsourcing, BuSINESS WEEK ONLINE, Oct. 27, 2003, at http://www.businessweek.com/technology/content/oct2003/ tc20031027_9655_tc1 19.htm (last visited Mar. 22, 2005).

45. As with the outsourcing of electronics manufacturing in the early $1990 \mathrm{~s}$, even companies who are outsourcing business-processes support are reluctant to disclose such a fact 
noted that India has become a constant theme in discussions between investors and executives, as executives are trying to show that they are at the forefront of this trend, rather than lagging behind and sacrificing crucial cost savings. Rajiv Chauhri, a portfolio manager of the Digital Century Technology hedge fund, stated that " $[e]$ veryone is facing the same problem - revenue growth has slowed, and they have to reduce costs. So increasingly, they're being asked to articulate their plans to move some development and back office to India. ${ }^{, 46}$

While the financial savings associated with outsourcing call centers are considerable, some companies feel that there are too many headaches involved in dealing with India. Despite the fact that there is a large population of highly skilled workers, many Indian workers do little more than what is specifically assigned. Many companies have experienced delays due to Indian workers not understanding what they were expected to do or not completing contingencies associated with the project. Managers think that many of the problems are a result of Indian workers not being onsite, and feel that these delays are more costly and outweigh the benefits of lower wages. ${ }^{47}$ In addition to delays, there

in an effort to avoid political unpopularity. See Pete Engardio, Corporate America's Silent Partner: India, BusInEssWEEK ONLINE, Dec. 15, 2003, at http://www.businessweek.com/ bwdaily/dnflash/dec2003/nf20031215_8942_db046.htm (last visited Mar. 22, 2005).

In the current political climate, politicians, pundits, and angry laid-off workers are hunting for scapegoats for America's largely jobless recovery. You can't find better targets than China and India, both of whom undeniably are gaining from the sweeping restructuring of American technology, financial services, and telecom companies. Companies from AT\&T Wireless (AWE), to Bank of America (BAC) are issuing pink slips at home while staffing up in Delhi, Bombay, and Hyderabad.

Id. However, as more and more firms recognize the financial benefit of such outsourcing, companies will be forced not only to follow the trend, but also to disclose their outsourcing to avoid falling stock prices. Again analogous to off-shore electronics manufacturing, companies who outsource will have higher stock prices and healthier returns on capitals. Companies such as Motorola and Lucent who were slow to sell off their domestic factories and outsource this sector were less competitive and heavily criticized. Id.

46. Id.

47. Many entrepreneurs are starting to feel that the benefits of outsourcing these jobs to India are overstated. For example, one startup in Austin, Texas, called the K3 group, employed only American labor because they felt there were too many costs associated with India that outweighed the savings. The business was started by Ryan Kinzy who had experienced these problems while working in a larger high-tech company that did outsource labor. He stated:

There were too many headaches in dealing with India. We often got spaghetti code that was functional, but couldn't grow .... The time difference was very difficult. The explanation, "They program while you sleep" doesn't hold water. Too often, a problem would arise and they would respond the next day with, "Well, we weren't sure what you wanted to do" - and a whole day was lost, time and again. Before long we were four months behind schedule. It was also very difficult to remotely manage a project unless you had a very strong infrastructure over there of U.S.-style managers. Finally, the rising costs over there make it tougher to justify.

David E. Gumpert, A New Tide in Offshore Outsourcing, BusINEsSWEEK ONLINE, Jan. 12, 2004, at http://www.businessweek.com/smallbiz/content/jan2004/sb20040112_0920.htm (last visited Mar. 22, 2005). Other companies have decided it is worth paying a little higher wages to avoid the remote, offsite employees. For example, a small company out of Boston, Massachusetts, 
are other hidden costs associated with outsourcing jobs to India. For example, one company that outsourced its software development to India had to spend more money to have the bugs and glitches repaired once it was returned than if they had just developed it in the United States. ${ }^{48}$ There are also costs related to setting up and managing operations abroad, such as paying domestic engineers to work late into the night so that they can communicate with the Indian teams, and possibly changing internal processes to accommodate offshore partners. ${ }^{49}$ Finally, even the cost of wages is starting to increase in India as more companies follow the trend of outsourcing there. As a result, many companies may be actively looking to places cheaper than India, such as Argentina or Colombia. $^{50}$

\section{TAX TREATMENT}

India has also made changes to its tax law designed to increase foreign investment. However, before these tax advantages can be properly understood,

called cMarket decided to do just that. See David E. Gumpert, U.S. Programmers at Overseas Salaries, BUSINESSWEEK ONLINE, Dec. 2, 2003, at http://www.businessweek.com/smallbiz/ content/dec2003/sb2003122_8887.htm (last visited Mar. 22, 2005). In looking for programmers, cMarket found that experienced American programmers would cost about $\$ 80,000$ per year, with benefits adding an additional $\$ 5,000$ to $\$ 10,000$. Id. On the other hand, they could hire Indian programmers for about $\$ 40,000$. Id. Jon Carson, the entrepreneur who started cMarket, liked the idea of saving that much money but did not want to push jobs away from this country. Also, he did not want to risk having all of the essential work being done by people he did not know and could not communicate with face-to-face. As an alternative, he decided to offer the jobs to Americans at a large discount to the going rate for experienced programmers: $\$ 45,000$. Id. Due to the down economy, he received many resumes from qualified, experienced programmers who were having trouble finding work. He feels that this resulted in giving him control over quality and timing that he would not have had if he had outsourced to India. One concern, however, is that offering Indian-style wages to American workers may cause a decline in the American standard of living, even though it would help solve the country's problems with creating jobs. Id.

48. In 2002, Empowered Software Solutions (ESS) earned approximately $\$ 500,000$ in revenues earned solely from fixing buggy software that was outsourced to India. See Kharif, supra note 44. ESS spent five months fixing the software intended for a web portal that contained missing code and pages that were not connected. Id. ESS said that they could have done the work originally for about $\$ 900,000$ here in the United States. Instead it was outsourced to India, and the Indian developer not only returned the application with many errors, but did so at $\$ 1$ million over budget. Id. When companies look at the total cost, rather than just wages, they will probably see that the cost is comparable to getting the work done domestically. However, many companies are unaware of all of the costs involved because they cannot accurately measure their productivity, efficiency and costs prior to and after outsourcing. One other hidden cost includes the potential loss of clients. While outsourcing companies claim that there is no harm to service quality or loss of customers, many are worried that their problem will not be accurately resolved because there is no on-site personnel to help customers. Many purchasers are transferring their business to companies with on-site technical support in order to ensure that their questions will be answered. There is also concern that businesses are sacrificing quality for cost, as software developed offshore is estimated to have about thirty-five to forty percent more bugs than software produced domestically. Id.

49. Id.

50. Id. 
one must first comprehend which entities constitute a company under Indian law. Businesses are governed by the Companies Act of 1956 (Companies Act) which extends to the whole of India. ${ }^{51}$ A company under this Act is a legal entity, separate from its members, directors and managerial personnel. A company has perpetual succession, limited liability, and its own rights and obligations, resulting in the existence of a corporate veil. ${ }^{52}$ With regard to income tax, the definition of "person" in the Income Tax Act of 1961 includes a company. ${ }^{53}$ Indian income tax is also expressed in terms of residency. A company is considered an Indian resident if it is an Indian company or if the control and management of its affairs are situated wholly in India during a given year. ${ }^{54}$ Therefore, if a company is incorporated in India, it qualifies as an Indian resident and would be subject to the Income Tax Act. As such, the company would be liable to India for its worldwide income, which is obviously something the company would want to avoid. ${ }^{55}$

If a company is not considered a resident under Indian law, its income is either defined by a tax treaty between the company's home country and India or by $\S 5(2)$ of the Income Tax Act. ${ }^{56}$ There has been much uncertainty over the

51. KHINDRIA, supra note 17 , at 90 .

52. Id. at $90-91$.

53. Under Chapter 2 of the Income Tax Act, "income tax shall be charged ... in respect of the total income of the previous year or previous years, as the case may be, of every person." C.I.S. Part I (1961), INCOME TAX ACT ch. 2, $\S 5(2)$ of the Ministry of Finance of the Government of India, New Delhi, Apr. 1, 1962, available at http://incometaxindia.gov.in/ Income $\% 20$ tax $\% 20$ act.asp (last visited Mar. 22, 2005) [hereinafter Income Tax Act]. This income is based on the sale of a company's products and provisions of its related services. KHINDRIA, supra note 17, at 161-62.

54. Id. See INCOME TAX ACT, ch. $2, \S 5(1)$.

55. Section 5(1) states the extent of a resident's tax liability as follows:

Subject to the provisions of this Income Tax Act, the total income in any previous year of a person who is a resident includes all income from whatever source derived which:

a. is received or is deemed to be received in India in such year by or on behalf of such person;

b. accrues or arises or is deemed to accrue or arise to him in India during such year; or

c. accrues or arises to him outside India during such year.

Id. See also KHINDRIA, supra note 17, at 161.

56. Section 5(2) defines a non-resident's income as follows:

(2) Subject to the provisions of this Income Tax Act, the total income in any previous year of a person who is a non-resident includes all income from whatever source derived which

a. is received or is deemed to be received in India in such year by or on behalf of such person

b. accrues or arises or is deemed to accrue or arise to him in India during such year.

Income Tax Act, ch. $2, \S 5(2)$

Explanation 1: Income accruing or arising outside India shall not be deemed to be received in India within the meaning of this section by reason only of the fact that it is taken into account in a balance sheet prepared in India. 
foreign company's tax liability to India. ${ }^{57}$ As a result, India has tried to simplify the assessment of taxation by introducing a system of advance tax rulings. ${ }^{58}$ In order to actuate the benefits of the rulings, a foreign company must determine which parts of its income are subject to tax in India. ${ }^{59}$ This income includes that which is derived outside of the country if it is received or deemed to be received in India. ${ }^{60}$ The nonresident company's income would also include income that accrues or is deemed to accrue in India. ${ }^{61}$ Thus, if a foreign company delivers goods to its joint venture in India, the income has been accrued in India and is subject to the Indian income tax even though no payment has been exchanged. ${ }^{62}$ The tax paid to India does not necessarily relieve the foreign company from any tax liability on its income owed to the company's home country. ${ }^{63}$ In order to minimize the burden of double taxation, many countries have entered into bilateral agreements to decide the amount of taxes each country will receive in international business transactions. ${ }^{64}$ India is authorized to enter into treaties with foreign countries, and the treaty would prevail over any inconsistent provision of the Income Tax Act. ${ }^{65}$ Where a tax treaty does exist, the corporate tax applicable to the foreign company can be the lower rate prevailing in either of the two countries. ${ }^{66}$ Consequently, it is essential for a foreign company to determine if its home country has signed such an agreement with India before commencing business there.

As part of India's continued rehabilitation of its tax code, on May 27, 1995, the President granted his assent to a Union Budget, presented by the Indian Finance Minister, which contains provisions beneficial to trade and industry. ${ }^{67}$ For example, the tax-exempt amount per year was increased from rupees 35,000 to $40,000{ }^{68}$ Also, the top $40 \%$ tax rate now applies to income

Explanation 2: For the removal of doubts, it is hereby declared that income that has been included in the total income of a person on the basis that it has accrued or arisen or is deemed to have accrued or arisen to him shall not again be so included on the basis that it is received or deemed to be received by him in India. Id. See also KHINDRA, supra note 17, at 173.

57. KHINDRA, supra note 17 at 174.

58. Id.

59. Id.

60. Most foreign companies make efforts to receive their income outside of India, this includes making sure that the income is not actually received by a bank in India that was opened by either the company or its agents. Id.

61. Id.

62. A foreign company can, however, arrange to pass the title of the goods to its joint venture company outside of India, the right to receive the payment has accrued outside of India, and as such, is not subject to Indian income tax. Id.

63. Id. at 180 .

64. Id.

65. Id.

66. Indian Inv. Ctr., supra note 9.

67. P. R. V. Raghavan, Tax and Forex Changes in India Aim to Increase Foreign Investment, 7 J. INT'L. TAX'N. 17, 17 (1996).

68. $I d$. 
levels starting at rupees 120,000 instead of the prior level of rupees 100,000. ${ }^{69}$ Payments and capital gains made by various Indian businesses have also been exempted from tax. ${ }^{70}$ The rate for import duties for capital goods has been greatly reduced, and there are no countervailing duties charged for certain industries. $^{71}$ Another beneficial change in the tax structure of India is the extension of the system of modified value added tax, or MODVAT, to additional industries. ${ }^{72}$ The justification for MODVAT was to limit the effects of multiple duties on excisable commodities used as imports in the manufacture of other excisable commodities. " "The extension of the MODVAT system to a large category of industries ... is expected to make capital-intensive industries and the export industry in India more competitive in the international market.",74

\section{SPECIAL ECONOMIC ZONES}

In addition to taxation, India is using other incentives to encourage foreign investment in free trade zones, export-oriented undertakings, and industrial disinclined areas. ${ }^{75}$ To encourage investment in the setting up of an industrial park or special economic zone, the government has provided for $100 \%$ income tax exemption for ten years within a block of fifteen years during a period ending March 31, 2006. ${ }^{76}$ All investments in export-oriented units and free trade zones are given automatic approval subject to sectoral norms. ${ }^{77}$ With

69. Id. X-Rates, Historic Look Up, at http://www.x-rates.com/cgi-bin/hlookup.cgi (n.d.) (last visited Mar. 2, 2005). The current conversion rate (as of October 30, 2003) is rupees 45.33 per USD 1.

70. For example, payments made by an Indian company engaged in the business of aircrafts, which acquires an aircraft or aircraft engine on lease for a foreign government or foreign enterprise under an agreement approved by the central government, is exempt from tax in India. Also, venture capital companies and funds are exempt from tax on income derived from dividends and long term capital gains from investment in equity shares in a venture capital undertaking. An Indian company in the business of developing, maintaining, and operating an infrastructure facility is also eligible for tax benefits, such as profits exempt from tax for the first five years, and thirty percent of its profits exempt for the following five years. Raghavan, supra note 67 , at $17-18$.

71. Id. at 18 .

72. Id. MODVAT is similar to the Value-Added Tax system used in European countries. It provides for an instant credit of excise duties paid on imports used in the manufacture of other excisable goods.

73. KHINDRIA, supra note 17 , at 157.

74. Raghavan, supra note 67 , at 18.

75. P. R.V. Raghavan, India's Recent Reforms Open the Way for Investment and Technology, 6 J. INT'L. TAX'N. 162, 162, 166 (1995).

76. INDUSTRIAL POLICY, supra note 18, at 23 ๆ 6.3.

77. The Manual on Foreign Direct Investment in India states:

The Development Commissioners (DCs) of [Export Processing Zones (EPZs)/Free Trade Zones (FTZs)] Special Economic Zones (SEZs) accord automatic approval to projects where:

(a) Activity proposed does not attract compulsory licensing or falls in the 
the exception of a few activities, up to $100 \%$ of FDI is permitted through the automatic route in special economic zones. ${ }^{78}$ India has also introduced incentives applicable to proposals for Electronic Hardware Technology Parks (EHTP) and Software Technology Parks (STP) to stimulate the electronics industry. ${ }^{79}$ All proposals for investment in these units are eligible for automatic approval if they meet the parameters required for the automatic route. ${ }^{80}$

The Indian government has established one Free Trade Zone and seven Export Processing Zones in order to achieve their "goals of promoting selfreliance, developing industries, acquiring technology and technical know-how, attracting foreign participation with secured returns on their investments and providing an export market ...."81 In these zones there are opportunities for imports and promotion of exports for both Indian and foreign citizens. ${ }^{82}$ Units within these zones are offered many incentives, such as exemption from customs duties and simplified clearance procedures on imported raw, tooling

services sector except IT enabled services;

(b) Location is in conformity with the prescribed parameters;

(c) Units undertake to achieve exports and value addition norms as prescribed

in the Export and Import Policy in force;

(d) Units undertake to achieve positive net foreign exchange earninings; and

(e) Unit is amenable to bonding by customs authorities.

Id. at 21 ๆ 5.1 .

78. Activities would require government approval for foreign direct investment, include the following:

1) arms and ammunition, explosives and allied items of defense equipments defense aircraft and warships;

2) atomic substances;

3) narcotics and psychotropic substances and hazardous chemicals;

4) distillation and brewing of alcoholic drinks; and

5) cigarettes/cigars and manufactures tobacco substitutes.

See id. at 39 Annexure I - II.

79. These schemes "offer a package of incentives and facilities like duty free imports on the lines of the EOU Scheme, deemed export benefits and tax holidays." Id. at 24 T 7.1 .

80. The Manual on Foreign Direct Investment in India states:

The Directors of STPs in respect of STP proposals; and the Designated Officers in respect of EHTP proposals accord automatic approval if:

(a) items do not attract compulsory licensing;

(b) location is in conformity with the prescribed parameters;

(c) unit is amenable to bonding by the Customs, and all the manufacturing operations are carried out in the same premises and the proposal does not envisage sending out of the bonded area any raw material or intermediate products for any other manufacturing or processing activity.

All proposals for FDI/NRI investments in EHTP/STP units are eligible for approval through automatic route subject to parameters listed in para 3.3.

Id. at 24 T 7.2.

81. See generally KHINDRIA, supra note 17 , at 40 . The one Free Trade Zone is located at Kandla (Gujarat), and is known as "KAFTZ". One of the seven Export Processing Zones is located in Santa Cruz, Maharashtra, and is used exclusively by the government to promote the setting up of units that manufacture electronic products. The remaining six are multiple-product zones and are located in Noida, Uttar Pradesh; Cochin, Kerala; Falta, West Bengal; Chennai, Tamil Nadu; Visakhapatnam, Andhra Pradesh; and Surat, Ahmedabad. Id.

82. Id. 
and packaging materials. Imports on capital goods are duty-free, and the zones are placed under Open General License, giving them a total waiver of licensing for imports of capital goods and production materials (but a unit within one of the zones cannot import items banned for import in other parts of India). One hundred percent non-resident equity participation is permitted in any form of organization, and non-resident enterprises are not required to associate with resident Indians in investment or participation. Finally, a foreign investor may freely repatriate his investment of capital and capital appreciation, profits invested back into the project, and dividends, after deduction of applicable taxes. $^{83}$

In addition to units produced in the zones above, a unit can set up in any other location if it proposes to export the bulk of its manufactured goods and services under the $100 \%$ Export-Oriented Unit (EOU) scheme. ${ }^{84}$ Under this scheme, industrial units that export their entire production for ten years, or five years for products liable to rapid technological change, are eligible for the same incentives as units in the zones, in addition to other incentives granted only to EOUs. ${ }^{85}$ These units are distinguished from other similar schemes in that they can be established anywhere in India, subject to locaional criteria, environmental laws, and land-use and zoning laws. ${ }^{86}$ Units must achieve a minimum local value added content of twenty percent, unless otherwise specified in the Import/Export Policy 1992-97. ${ }^{87}$ A unit may also act as both a domestic and export-oriented unit, but it must maintain separate accounts and have separate identities; however, separate legal identities are not required. ${ }^{88}$

The EOUs are eligible for many of the same benefits offered to units in the Free Trade and Export Processing Zones. However, they are also offered many additional benefits, such as permission to achieve $100 \%$ exports in an agreed upon phase, which the Board may relax on a merit basis if the exports are at least five percent of production. EOUs may take advantage of a consecutive five year tax holiday, taken at the Unit's option during the first eight years of operation, if the EOU is established in a zone. Certain approved units are issued cards for identification purposes, which entitle them to specific enumerated benefits (entitled "Green Cards"). EOUs are considered essential

83. Other incentives include: a supply of power and good quality water assured at reasonable rates; all excisable goods produced or manufactured in a zone are exempt from any duty they would otherwise be liable to under the Central Excise and Sales Act; goods obtained from the domestic tariff area, which would normally be subject to excise, used by the industries within the zone for, or in connection with, production of goods intended solely for export are exempt from excise duties and other levies; the zones have all other infrastructural facilities; and units within the zones are typically entitled to complete tax holidays for a certain number of years, and to full reimbursement of central sales tax paid on their purchases made from domestic tariff areas on items used in the production of goods intended for export. Id. at 40-41.

84. Id.

85. Id. at 42 .

86. Id.

87. Id.

88. Id. 
consumers in areas such as power, iron and steel, giving them higher priority.

Finally, these Units have priority for release of foreign exchange, in which the Reserve Bank disposes of their applications within four days. ${ }^{89}$

The EOUs, Export Processing Zones, and Free Trade Zones are important tools that an investor should consider in determining how to structure an investment in India. They allow foreigners to make $100 \%$ investments in large, medium and small export-oriented industries. ${ }^{90}$ In addition to the other benefits India offers foreign investors, such as low cost technical labor resources, investors in these zones also receive cheap land, import entitlements of raw materials and technology, and tax and other financial incentives. They also receive priority on loans, transportation of goods, and supply of cement and power. ${ }^{91}$ In sum, a rather attractive package indeed!

\section{ENTRY STRATEGIES FOR FOREIGN DIRECT INVESTMENT IN INDIA}

Foreign direct investment is the acquisition of ownership of a business or organization in a foreign nation. ${ }^{92}$ Typically, an investor may accomplish this in one of three ways: (1) an investor can establish a new branch or subsidiary; (2) an investor can acquire the controlling share of an existing firm; or (3) an investor can participate in a joint venture. ${ }^{93}$ In addition to the investment of capital, FDI involves the transfer of technology and business expertise, as well as access to a global market. ${ }^{94}$

In most industries, any of the above strategies may be used by a foreign company to invest in India. Indian law distinguishes a "corporate body," which is a company incorporated outside of India and includes both the Indian and foreign company, from a "company," which is an entity registered under the Companies Act and refers only to the Indian company. ${ }^{95}$ A corporate body, or foreign company, must also comply with the Companies Act of 1956 and must register themselves with the Registrar of Companies (ROC) within thirty days of setting up its place of business in the country. ${ }^{96}$ Most foreign investors use a company incorporated in India as their form of business. ${ }^{97}$ Once incorporated

89. Id. at $42-43$.

90. Id. at 45 .

91. Id.

92. James D. Nolan, Note, A Comparative Analysis of the Laotian Law on Foreign Investment, the World Bank Guidelines on the Treatment of Foreign Direct Investment, and Normative Rules of International Law on Foreign Direct Investment, 15 ARIZ. J. INT'L \& CoMP. L. 659,663 (1998).

93. Id.

94. Id.

95. PRICE WATERHOUSE, supra note 15 , at 83.

96. SEC'Y FOR INDUS. ASSISTANCE, INDIAN MINISTRY OF COMMERCE AND INDUS., ENTRY STRATEGIES FOR FOREIGN INVESTORS, at http://siadipp.nic.in/policy/entry.htm (n.d) (last visited Mar. 22, 2005) [hereinafter SIA].

97. Price Waterhouse, supra note 15 , at 83. 
and registered in India, the company will be subject to the same regulations as a domestic company. ${ }^{98}$ Foreign ownership in these companies can be up to $100 \%$ depending on the business plan, the prevailing investment policy of the government, and the receipt of the required approvals. ${ }^{99}$ A company can be either a public or private company as determined by its articles of association. ${ }^{100}$ There are generally no restrictions on the residency or citizenship of the board members, and employee representation on the board of directors is not compulsory. ${ }^{101}$

A foreign company can also operate in India by creating a joint venture with an Indian partner. A joint venture may provide advantages to the foreign company, such as access to the established distribution and marketing process of the Indian partner, use of the partner's financial resources, and access to the Indian partner's contacts, which can help streamline the process of setting up operations in a foreign country. ${ }^{102}$ However, since joint ventures are usually formed for very specific and limited purposes, they are not prevalent in practice. ${ }^{103}$

One other possible strategy for a foreign company is to set up a liaison office in India. This strategy is used to collect information about possible market opportunities and to provide information about the home company and its products to potential Indian consumers. ${ }^{104}$ A liaison office is not allowed to conduct any trading or commercial activities in India other than collecting and transmitting information to the foreign company; thus, it cannot receive any income in India. ${ }^{105}$ The opening and operation of a liaison office must comply with the regulations in the Foreign Exchange Management Act of 1999 (FEMA). Approval of the RBI is required to open this type of office, and the Indian government has imposed standard conditions for it. ${ }^{106}$ For example, the

98. SIA, supra note 96.

99. Id.

100. The Companies Act provides that a private company is deemed a public company if any of the following conditions are met:

1. One or more corporate bodies hold twenty-five percent or more of its paidup share capital. (For this purpose, foreign companies are not considered corporate bodies.)

2. It holds twenty-five percent or more of the paid-up share capital of a public company.

3. Its average annual turnover is above a prescribed amount (at present rupees ten million).

PRICE WATERHOUSE, supra note 15 , at 84.

101. However, government approval is required for the terms of appointment of expatriates as either full-time managers or board members if the expatriate's stay in India prior to appointment is less than one year. Id. at 90.

102. SIA, supra note 96.

103. PRICE WATERHOUSE, supra note 15 , at 83.

104. SIA, supra note 96.

105. Id.

106. Permission to set up such offices is initially granted for a period of three years; however, this may be extended from time to time. The Liaison office must also file an annual 
expenses of the liaison office are to be satisfied by the foreign company's inward remittance of foreign capital, and the office should not charge or receive any income from Indian consumers for the liaison services. ${ }^{107}$

A foreign company may also set up a temporary site office in India if it is planning to execute a short-term project in the country. The specific purpose of the project must be approved by the RBI, but permission is usually granted where projects are financed by an Indian bank or financial institution, or by a multilateral or bilateral international financial institution. ${ }^{108}$

With the exception of airlines, shipping and banking companies, which were allowed to open branch offices on a reciprocal basis in the past, branches of foreign companies have been asked to convert into Indian corporations. This requires a certain percentage of Indian participation in the equity of the company, based on the nature of the business. ${ }^{109}$ As a result of this policy, branch offices had almost ceased to exist in India, and foreign companies were limited to liaison or site offices. The government has expanded the permissive approval of branches; now a foreign company engaged in manufacturing or trading activities abroad can also set up a branch office in India. ${ }^{110}$ However, the purposes of these branch offices do have some limitations. ${ }^{111}$ The branch office is not allowed to carry out manufacturing activity directly, and permission from the RBI to set up a branch office is granted on a case-by-case basis. ${ }^{112}$

activity certificate, or something similar from a Chartered Accountant to the RBI. Id.

107. Id.

108. Id.

109. PRICE WATERHOUSE, supra note 15 , at 83.

110. Id.

111. Branch offices for foreign manufacturing and trading companies can be opened for the following purposes:

a. to represent the parent company or other foreign company in various matters in India, like acting as a buying or selling agent in India;

b. to conduct research work in the area in which the parent company is engaged, [provided the results of the research are available to Indian companies];

c. to conduct import and export trading activities;

d. to promote possible technical and financial collaborations between Indian and overseas companies;

e. to render professional or consultancy services;

f. to render services in information technology and development of software in India; and

g. to render technical support to the products supplied by the parent or foreign companies.

SIA, supra note 96.

112. "RBI normally considers the operating history of the applicant company worldwide and its proposed activities in India for granting the approval." Confederation of Indian Industry, http://www.ciionline.org/Services/74/default.asp?Page=Entry\%20Strategies.htm (last visited Mar. 31, 2005). 


\section{THE GROWTH OF FOREIGN DIRECT INVESTMENT THROUGHOUT THE WORLD.}

Throughout the history of international law, two conflicting views on foreign investment have emerged. The first view is entitled the "neo-classical theory," and its adherents believe that foreign investment is beneficial to developing states. ${ }^{13}$ Under this belief, investment from more developed to less developed countries should be facilitated because it allows for the transfer of knowledge, skills, technology, capital, and employment. ${ }^{114}$ Some proponents of this paradigm go as far as believing that "developing countries could not survive without multinational corporations and foreign investment." contradictory view, labeled the "dependency theory," holds that FDI is detrimental to a country's development and should not be encouraged. ${ }^{116}$ Believers in the dependency theory argue that foreign investment is solely a means for a multinational corporation to circumvent a foreign country's regulations in order to serve the developed country in which they have their headquarters. ${ }^{117}$ As a result, the developing country becomes dependent on the foreign investor, and in return for serving the interests of the home economy, the developing country gives up control and autonomy in determining its own policy. ${ }^{18}$ It was belief in this theory that resulted in stringent restrictions, if not total prohibition, of FDI in developing countries up until recent history.

As a result of the more modern view towards FDI, there are few countries that engage in restrictive trade policies, because it is now generally understood that FDI is essential to keep one's economy from staggering. Countries now know that inward FDI plays an important role in increased exports and fast and sustained economic growth. "It is increasingly recognized that foreign direct investment (FDI) is an important component of an effective strategy to develop solutions to the global economic crisis, in part because it creates a flow of nondebt equity into developing countries and promotes sustained growth and employment." 119 Worldwide FDI has grown from $\$ 182.6$ billion in 1995 to $\$ 865.5$ billion in $1999,{ }^{120}$ of which developing countries received nearly $\$ 200$ billion, an increase of $15 \% .{ }^{121}$ This growth seems to be increasing at an even faster rate now; in 2000, FDI inflows may have exceeded $\$ 1.1$ trillion, over

113. Nolan, supra note 92 , at 664 .

114. Id.

115. Id.

116. Id.

117. Id. at 664-65.

118. Id. at 665 .

119. Daniil E. Fedorchuck, Acceding to the WTO: Advantages for Foreign Investors in the Ukrainian Market, 15 N.Y. INT'L L. REV. 1, 2 (2002).

120. Id. at 6-7.

121. Kevin C. Kennedy, Global Trade Issues in the New Millennium, Foreign Direct Investment and Competition Policy at the World Trade Organization, 33 GEO. WASH. INT'L L. REV. 585, 597 (2001) [hereinafter Global Trade Issues]. 
$14 \%$ of the FDI in $1999 .{ }^{122}$ Further, the number of bilateral investment treaties and double taxation treaties has increased, reflecting the "growing role of FDI in the world economy and the desire of countries to facilitate it." 123 There are predictions that FDI will continue to play an important role in the world's economic system, as globalization and cross border expansion is likely to increase in the future. ${ }^{124}$

These changes are a result of the transformation that developing countries have encountered as they have gone from being hostile towards FDI in the $1960 \mathrm{~s}$ and $70 \mathrm{~s}$ to actively pursuing it in the late $1980 \mathrm{~s}$ and $90 \mathrm{~s}$. The hostility in the 1960 s and 70 s was partially a result of large multinationals expanding abroad and opening new plants by acquiring locally-owned enterprises. ${ }^{125}$ This concern caused developing nations to adopt fairly common approaches to regulate foreign investment. First, developing nations either severely limited or prohibited acquisition of host nation enterprises. ${ }^{126}$ Second, any new investments permitted were required to own certain percentages of local equity participation. For example, some areas of investment would typically be reserved exclusively as state owned enterprises, and areas that allowed investment required that the foreign equity percentage be capped at forty-nine percent. ${ }^{127}$ The investment that was allowed would have to be approved by a government agency, which usually had discretion in granting exceptions. ${ }^{128}$ Most concerning for potential investors, however, was that many of the restrictions were unwritten and created transparency issues for the unknowing investor. These "drawer regulations" would be enacted after the investor had spent considerable time and money in research and preparation on the investment. With no concise written laws, one cannot truly determine if a financial contribution toward a project in another country is attractive, as regulations such as tax and labor laws that affect the return are unknown. As a

122. Fedorchuck, supra note 119 , at 7.

123. Kennedy, supra note 121 , at 597.

124. Fedorchuck, supra note 119 , at 58.

125. RALPH H. FOLSOM ET AL., INTERNATIONAL TRADE AND INVESTMENT IN A NUTSHELL 179 (2000). This author refers to this result as Post Colonial Traumatic Syndrome (PCTS), describing the shock entities go through when they transition from following a definitive set of laws and policies dictated to them to creating laws to govern themselves. When a multinational company expands into a developing country, part of the investment includes a transfer of technology and management skills, which the company teaches the local workers. After a period of time the local content of labor is increased, and eventually the company is run by local management. PCTS may occur when the local management is unable to run the company as effectively as the foreign management, and creates policies that do more harm to the company than good. See id.

126. Id.

127. Id.

128. Id. Frequently, the agency followed a statute providing a list of criteria for approving foreign investment. Common criteria included agreeing on the number of workers to be employed, mandating the use of domestic materials and parts that would be used, requiring financing to be obtained from abroad, consideration of the effects on existing domestic businesses, and establishing research and development facilities in the nation. Id. at 179-180. 
result, foreign investment is deterred from countries with drawer regulations and contributed instead to countries with automatic approval processes or concise and transparent investment laws. While many countries have tried to address this with investment codes and written regulations, this is still a concern when a government agency has discretion to allow an investment. Another common approach of developing nations has been to encourage or coerce existing foreign partners in joint ventures to sell majority ownership to local individuals, entities owned by local individuals, or the state. ${ }^{129}$

After several years of these restrictive rules, many developing nations began to wonder why nationals had not increased their rate of development. They began to realize that shifting ownership from foreign to local was not a guarantee of economic development in the nation as a whole. ${ }^{130}$ As a result, these governments tried to encourage foreign investment by allowing substantially expanded foreign ownership under either written or unwritten exceptions to foreign investment laws. ${ }^{131}$ For example, if the foreign investor transferred the most modern technology to the host nation or located its plant in a zone of high unemployment or one designated for economic development, exclusive ownership would be allowed. ${ }^{132}$ In the 1980 s and 90 s, developing nations' attitudes towards foreign investment began to change even more dramatically. Many attribute this change to "(1) the debt crisis in the early $1980 \mathrm{~s},(2)$ the opening to investment by many nonmarket economies, and (3) the election of less 'populist' governments in many developing nations."133

As a result of the frustration of the past, a new paradigm for foreign investment has emerged. The present trend in national legislation throughout the world since the 1980s is to adopt laws that create a favorable investment climate to attract foreign investors. ${ }^{134}$ Many countries even go as far as offering super-national treatment to foreign firms, giving them incentives that are not available to domestic firms. ${ }^{135}$ Joint ventures with local ownership are still encouraged, but are now voluntarily formed rather than compelled. ${ }^{136}$ Also, many governments around the world are privatizing their previously state-

129. Id. at 181 .

130. Id. at 183 .

131. Id.

132. Other strategic areas where foreign investment would be totally allowed included those with a high export percentage of its output, or those where research and development facilities would be located in the nation. Id.

133. Id.

134. Kennedy, supra note 121 , at 597.

135. Shang-Jin Wei, World Bank Group et al., Can China and India Double Their INWARD FOREIGN DIRECT INVESTMENT? 2, http://www.nber.org/ confer/99/indiaf99/IndiaChina-FDI.PDF (Nov. 30, 1999) (last visited Mar. 22, 2005). For example, China offers benefits to foreign firms such as reduced taxes, or an elimination of them altogether, which are not offered to domestic firms. Id.

136. "Sometimes continuing restrictions on foreign ownership of land induces a joint venture, as might risk analysis which suggests limiting equity participation, even though market studies encourage entering the market." FOLSOM ET AL., supra note 125, at 184. 
owned enterprises, opening new windows of opportunity for foreign investors. ${ }^{137}$ Many developed countries have privatized almost all of these enterprises, even industries with a close relation to national security and government control of their nationals, and these former state-owned enterprises are no longer tied to a political arena. ${ }^{138}$ Developing countries have also participated in the privatization process, but to a more limited extent. However, these developed countries have recently begun reassessing the potential for investment by the private sectors in areas of public services and physical infrastructure, and have actively been selling off state-owned enterprises. ${ }^{139}$

Developing and transitioning countries have also started adopting other liberalization policies in addition to privatization, such as deregulation and implementation of measures that safeguard effective competition. In fact, since 1990 , over thirty-five developing countries have enacted or substantially revised their competition laws in efforts to become more attractive destinations for foreign direct investment. ${ }^{140}$ Also, developing countries and non-market economies have reinterpreted their restrictive investment laws in favor of foreign investors and have subsequently replaced them with laws encouraging investment. ${ }^{141}$

One of the most successful examples of this transformation is China, which had practically zero foreign investment in the 1970 s, but is now a major host country of FDI and the largest developing host country. ${ }^{142}$ Investment in China has grown exponentially, as FDI in 1997 was $1,200 \%$ more than what it was in $1990 .{ }^{143}$ China is obviously an attractive destination for FDI, and many consider it "the world's strongest magnet for overseas investment."144 As a result of the increased FDI, China has experienced increased export expansion and significant overall growth.

Companies want to invest in countries where they can find low cost resources, such as labor. Countries are competing for the foreign investment dollar. So why has a country such as India, with a multitude of benefits for investors, including an open and liberal investment policy, not been able to succeed in attracting this foreign investment?

137. Joseph C. Blasko, Overcoming the Legal and Historical Obstacles to Privatization:

The Telecommunications Sector in Thailand, 30 CASE W. RES. J. INT'L L. 507, 507 (1998).

138. Id. at 508 .

139. Id.

140. The INT'L BANK FOR RECONSTRUCTION AND DEv. ET AL., A FrameWORK FOR THE DESIGN AND IMPLEMENTATION OF COMPETITION LAW AND POLICY V (1999).

141. FOLSOM ET AL., supra note 125 , at 184.

142. WEI, supra note 135.

143. Id. at 4.

144. Id. at 2 


\section{Why INDIA HaS Not ACHIEVEd ITS POTENTIAL}

Despite the multiple benefits mentioned above, India has not achieved its potential as an attractive destination for foreign investment. In the words of one expert, "India's investment climate is weak, limiting productivity gains and thus future growth and poverty reduction." high costs on firms, which lowers profits and deters new companies from investing in India. Foreign direct investment, as a share of the gross domestic product (GDP), was less that one percent in 2002 and 2003 in India, while representing four percent in China, and anywhere between two to three percent in many other emerging markets. ${ }^{146}$ "[I]n many areas India lags behind other emerging market economies, and if it could achieve Chinese or Thai levels in distinct investment climate areas, its growth acceleration would be even more dramatic." 147

\section{INDIA'S ECONOMIC HISTORY}

In order to appreciate India's treatment of foreign investment, it is important to understand India's economy. India was invaded by Europeans, primarily the English, who arrived in the early seventeenth century. By the eighteenth century, India was forced, for the first time, into a subordinate role within a world system, based on industrial production rather than agriculture. ${ }^{148}$ The English criticized India's past achievements and customs for lacking Western intellectual and technical aspects. The English tried to "civilize" India by importing these improvements. ${ }^{149}$ In addition, the English felt it was their responsibility to govern India until Indians could rule themselves. ${ }^{150}$ The

145. Nicholas Stern, World Bank Group, Abstract: Public Finance and Policy for Development: Challenges for India, NIPFP Silver Jubilee Lecture, at http://nweb18.worldbank.org/SAR/sa.nsf/Countries/India/7F6A6C684145A7FD85256B20002 C4510?OpenDocument (last visited Mar. 22, 2005) [hereinafter Stern Abstract].

146. Carter, supra note 27.

147. In 1999, FDI inflows in India were $0.5 \%$ of GDP, as compared to FDI inflows in China at $3.9 \%$ of GDP, and Thailand at $5 \%$. IMPROVING INVESTMENT CLIMATE, supra note 29, at 5 .

148. James Heitzman \& Robert L. Worden, History of India essay, INDIAN CHILD, Oct. 1 , 1996, at http://www.indianchild.com/history_of_india2.htm (last visited Mar. 23, 2005).

149. Federal RESEARCH Division, U.S. LibraRY OF CONGRESS, INDia (2003), http://countrystudies.us/india/16.htm (last visited Mar. 31, 2005) [hereinafter INDIA].

150. The British Parliament enacted several laws in an effort to regulate India. Among them were:

1. The Regulating Act of 1773 , which gave the British supervisory rights over the Bengal, Bombay, and Madras presidencies in an effort to bring order in territories under company control;

2. The India Act of 1784 , which gave the Parliament greater control by establishing the Board of Control, whose members were selected from the cabinet; and 
British implemented new models of mass production in India, which resulted in the suffering, and ultimately the destruction, of many of the craft and cottage industries that thrived prior to the British invasion. ${ }^{151}$ While this regime worked well in England, arguably it resulted in the destruction of much of the culture and progress that India attained. Many institutions, such as universities and communication industries, were utilized to serve British economic interests rather than those of India. ${ }^{152}$ As a result, "[a] country that in the eighteenth century was a magnet for trade was, by the twentieth century, an underdeveloped and overpopulated land groaning under alien domination."

India did inherit some positive changes from England, however. Throughout the $1850 \mathrm{~s}$, the British introduced three "engines of social improvement": the railroad, the telegraph, and a uniform postal service. ${ }^{154}$ These advancements made communication between rural and metropolitan areas easier and faster and facilitated the transportation of raw materials and goods from one part of the country to the other. Nonetheless, while India was left with a number of resources from the British raj, these resources were wrapped in a cocoon-like bureaucracy.

India gained political independence from Great Britain in 1947 and sought to gain financial independence as well. The Indian government adopted an autonomous policy in an attempt to improve the Indian economy, and was not amenable to foreign trade. ${ }^{155}$ India placed strict controls on imports and

3. The Charter Act of 1813, which recognized the British moral obligation of enacting just and humane laws in India.

Id. Also, in an attempt to make the Indian business climate more professional, the governorgeneral, Charles Cornwallis, changed the business structure. He separated commercial and administrative functions, declared private trade among company employees illegal, and compensated company servants with generous salaries. In an effort to increase revenues, two systems were created. Id. The first was the Permanent Settlement system, or zamindari system, in which taxes were fixed in return for ownership of large estates. In this system, however, the state was precluded from expanding the agricultural sector. The second system was the peasant settlement system, or ryotwari system, under which peasant farmers had to pay annual taxes directly to the governments. Id. Neither of these systems worked, however, creating greater stratification between the classes. More and more people began to rely on agriculture for survival as they lost their jobs and lacked any other opportunities for employment. Id. The British felt it was their duty to educate the Indians by teaching them literature and culture from England. Unfortunately, this effort had the result of reinforcing the stratification among the different classes, as the western-educated, Hindu elite initiated many reforms in response to government policies, the poorer, peasant Muslims failed to do so. As a result, the British left India in a state of turmoil, and despite their efforts, England was unable to make India respond to a system that did not suit their country. See generally id, at http://countrystudies.us/india/ (last visited Mar. 31, 2005).

151. Heitzman \& Worden, supra note 148.

152. Id.

153. Id.

154. InDIA, supra note 149 , at http://countrystudies.us/india/16.htm.

155. See id. at http://countrystudies.us/india/21.htm (last visited Mar. 31, 2005). India was sensitive to foreign domination; fearful that something similar to the Raj would occur again, and as a result, adopted these protective governmental policies, even once the period of colonialism had ended. See id. at http://countrystudies.us/india/94.htm. 
exports, and essentially isolated itself from the global market. Foreign investment in the private sector was tightly regulated, and it was believed that public ownership of basic industries was necessary to guarantee development in the interest of the whole population. ${ }^{156}$ Indian officials believed that trade was biased towards developing countries, so their policy was aimed at selfsufficiency in most products through import substitution, with only the cost of residual import requirements covered by exports. ${ }^{157}$ The government ensured a marginal and highly circumscribed role of FDI in the country by developing strict control under the Foreign Exchange Regulations Act (FERA) and the Monopolies and Restrictive Trade Practice (MRTP). ${ }^{158}$ The FERA capped foreign equity participation at forty percent in order to control foreign exchange outflows arising out of dividend and royalty payments. ${ }^{159}$ The MRTP discouraged large enterprises from being developed, and as a result, prevented economies of scale from being realized. ${ }^{160}$

Accordingly, India played a relatively small role in the world economy, and its relative importance declined. Its share of world trade shrank from $2.4 \%$ in 1951 to $0.4 \%$ in $1980{ }^{161}$ India tried to generate the foreign exchange it needed from the import of oil and high-technology capital goods by emphasizing exports throughout the 1980s. ${ }^{162}$ However, in the early $1990 \mathrm{~s}$ India's share of world trade still stood at only $0.5 \% .{ }^{163}$ India was politically and economically unstable, and the international community lost confidence in India's economic viability. Consequently, India was forced to liberalize its economic policy and open its doors to foreign investment. ${ }^{164}$ To achieve this liberalization, the Indian government introduced the New Industrial Policy in July of 1991 , which, as previously discussed, greatly relaxed regulations on foreign investments.

156. Doing Business in India - India Trade, INDIAN CHILD, at http://www.indianchild.com/ india_trade.htm (last visited Mar. 31, 2005) [hereinafter Doing Business in India].

157. Id.

158. Kishor Sharma, ECON. GROWTH CTR., YAle UnIV., EXPORT Growth IN INDIA: HaS FDI PLAYED A RoLE? 4, http://www.econ.yale.edu/growth_pdf/cdp816.pdf (July 2000) (last visited Mar. 23, 2005).

159. Id. at 4.

160. Id. The MTRP controlled the expansion and structure of large businesses in an effort to prevent the concentration of economic power and to curb restrictive policies. Id.

161. Doing Business in India, supra note 156.

162. Id. The Indian economy improved somewhat in the early $1980 \mathrm{~s}$, primarily due to investments made by Indian citizens. However, these funds were limited and eventually the government was forced to turn to foreign aid to stimulate growth, resulting in a severe deficit. In addition, the central government fell, creating political instability. Jatana, supra note 15 , at 332.

163. Doing Business in India, supra note 156.

164. Jatana, supra note 15 , at 332 . 


\section{THE EFFECTS OF THE REFORM POLICY IN 1991}

The reform program in 1991 improved the FDI inflows in India, and when compared to the country's past performance, the program has proven to be a boon for the country. For example, FDI inflows increased from approximately USD one billion during the 1980 s to USD 9.8 billion during the 1990-97 period. ${ }^{165}$ Also, the percentage of FDI in the GDP grew from about $0.2 \%$ during the 1970 s and 80 s to over $3 \%$ in 1997 . By then, India had become the ninth largest recipient of foreign direct investment by developing countries. $^{166}$ The Industrial Policy of 1991 also had a positive effect on the GDP. After the reform program, GDP growth went from 5.5\% per year in the $1980 \mathrm{~s}$ to an average growth of $6 \%$ in the 1990 s, peaking in $1996-97$ at $7.8 \%{ }^{167}$ One of the main reasons for this increased growth was the increase in private investment, which grew at a rate of $20 \%$ per year in real terms from $1992-93$ to 1996-97. ${ }^{168}$

While these factors indicate a positive trend for investment in India, one might still contend that the investment climate in India is far from satisfactory and has not achieved its potential. Indeed, the growth in private investment has slowed by $3.4 \%$ per year for the period $1997-98$ to $2001-02$. $^{169}$ India's GDP growth has also slowed to an average of $5.75 \%$ per year from 1997 to $1998 .{ }^{170}$ "Although such growth is high by international standards, the deceleration of private investment and growth has emphasized the need for what Indian policymakers are calling 'second generation reforms'."171 Also, there is a huge difference between the levels of approved and actual FDI. In January 1999, actual inflows of FDI were USD sixteen billion, less than thirty percent of the approved USD fifty-four billion. ${ }^{172}$ In the words of a respected economist, "the system just does not work as it is supposed to. The rules may be liberal in principle ..., [but] delays, complexities, obfuscations, overlapping jurisdictions and endless request for more information remain much the same as they have always been." 173 In addition, one of the greatest disappointments from India's economic development plan has been the failure to reduce the country's widespread poverty levels. As of mid-2003, about 260 million Indians lived below the poverty line. ${ }^{174}$

165. SHARMA, supra note 158 , at 7 .

166. Id.

167. IMPROVING INVESTMENT CLIMATE, supra note 29.

168. Carter, supra note 27.

169. Id.

170. IMPROVING INVESTMENT CLIMATE, supra note 29.

171. Id.

172. ShARMA, supra note 158 , at 8 . This is even lower in the infrastructure sector, where only sixteen percent of the cumulative approvals converted into actual investment. In the telecommunications sector the rate was fifteen percent, and in the oil refining sector it was eleven percent. Id.

173. Id. Quoted in Economist, Feb. 22, 1997, at 8.

174. Carter, supra note 27 . The government's poverty line is based on an income that 


\section{INEFFICIENCIES}

There are many possible explanations for the aforementioned slow down in growth. As discussed above, India is well positioned with determinants such as its local market size and its vast supply of well-educated, low-cost workers. When these factors are emphasized in comparing FDI competitiveness, India ranks near the top of the list. ${ }^{175}$ However, India's potential competitiveness is offset by investment climate bottlenecks. ${ }^{176}$ One indication of a country's competitiveness is the productivity dispersion of firms that operate there. Higher dispersion levels show that less efficient producers are not being forced to become more productive, usually because the producer is receiving subsidies or other protection from the government. ${ }^{177}$ This reduces the incentive for efficient producers to increase their productivity or to expand because their competition is being subsidized for less production. ${ }^{178} \mathrm{~A}$ liberal and open trade policy makes markets competitive, challenging domestic monopolies, while at the same time ensuring against possible abuses by foreign investors. ${ }^{179}$ India, however, has a very high productivity dispersion ratio, higher than that of other East Asian countries, which indicates that there is room to increase competition in India, forcing less productive firms to either become more efficient or shut down. $^{180}$

would be sufficient to be able to satisfy minimum nutritional standards. As a result, most people above the poverty line in India have low levels of consumption compared to the rest of the world. Id.

175. IMPROVING INVESTMENT CLIMATE, supra note 29. "A.T. Kearney publishes an index of FDI competitiveness that combines these elements, with an emphasis of market size and labor costs. India ranks near the top of the list at number 7." Id.

176. Id.

177. Id.

178. Id. As competition is increased in a country due to additional firms and an influx of more efficient businesses, the local firms have a greater incentive to improve their productivity.

Loss of protection and greater competition from foreign firms can drive inefficient domestic producers to better exploit scale economies, eliminate waste, reduce managerial slack or ' $x$ inefficiencies', adopt better technologies or shut down. As a result, productivity dispersion should shrink as productivity levels rise in the face of greater competition.

Id.

179. Kennedy, supra note 121 , at 599.

The implementation of a transparent and effective competition law and policy can be an important factor in enhancing the attractiveness of an economy as a site for foreign investment and in maximizing the benefits of foreign investment. Likewise, local firms will have the same ability to prevent abuses by foreign investors through a transparent and effective competition law and policy.

Id.

180. ImProving INVESTMENT Climate, supra note 29. In textiles, garments, and electronics, India has a dispersion ratio of approximately five, while in Korea the ratio is just over two, and the ratio in Malaysia and Thailand are just under three. Id. 


\section{EXCESSIVE REGULATIONS AND CORRUPTION}

One reason the competitive environment has not improved in India is that efficient firms do not want to deal with what they perceive as excessive regulations for entry and exit. Despite the government's valiant efforts to simplify investment procedures, India remains a maze of restrictive laws and policies. ${ }^{181}$ As a result, India still has longer median days and higher permit requirements than most other countries. ${ }^{182}$ There are many examples of hurdles that foreign businesses have had to face in order to invest in India. One such example, given by the Confederation of Indian Industry, is that of a typical foreign power project. It is reported that such a project needed forty-three clearances from the central government, as well as an additional fifty-seven at the state level. ${ }^{183}$ One can easily argue that this cumbersome system resulted in a cumulative rate of approved foreign investment that was actually realized at the rate of only twenty-five percent between 1991 and $1999 .^{184}$

Excessive regulation and corruption are also detrimental to India's attempt to attract foreign investment money. "One of the most discouraging and enduring characteristics of investing abroad, in nonmarket as well as developing nations, is persistent and deeply rooted corruption. Government officials view openings to foreign investment as an opportunity to 'cash-in' on the enormous amounts of funds changing hands." 185 Studies have shown that countries with high levels of corruption and red tape receive less foreign investment from all major source countries, especially from the United States. ${ }^{186}$ One subjective corruption index rated India 7.1 and China 6.5 on a scale of zero to ten, with ten being the most corrupt. ${ }^{187}$ Both countries also have high bureaucratic burdens, further worsening their investment climates; India has a rating of 5.1 and China is rated at 4.58 on a scale of one to seven. ${ }^{188}$

While these cross-country indicators rank India close to China in terms of corruption and rule of law, there are other objective measures that capture other costs not reflected in these indicators. For example, in looking at the amount of time plant managers in India spend dealing with government officials, India

181. FOLSOM ET AL., supra note 125 , at 184.

182. IMPROVING INVESTMENT ClimATE, supra note 29. "Relative to China, starting a business in India requires 10 permits compared to 6 in China, and the median time is 90 days in India relative to 30 days in China." Id.

183. Id.

184. Id.

185. FOLSOM ET AL., supra note 125 , at 184.

186. WEI, supra note 135 , at 3 . This is mainly considered to be a consequence of the United States Foreign Corrupt Practice Act (FCPA), which confronts U.S. investors, and until 1999 made the U.S. the only source country in the world that penalizes its firms for bribing foreign governmental officials. Id.

187. Id. This is compared to 0.9 in Singapore and 4.7 in Malaysia. This index was completed by Transparency International. Id.

188. Id. In comparison, Singapore had a rating of 2.08 and Malaysia had one of 3.63. Id. 
ranks less favorably than most other developing countries. ${ }^{189}$ One other regulatory obstacle for businesses in India is dealing with customs officials. This problem has two components: the average delay in goods being cleared and the variances in clearance time. The average clearance time is about fifty percent longer in India than in Korea and Thailand. More importantly, however, is the variance in delays, as this uncertainty forces firms to keep a greater inventory of materials on hand. ${ }^{190}$ This manifests itself as an "additional tax" on businesses because they incur interest and storage costs and tie up resources that could be used more productively. ${ }^{191}$ In addition to the bureaucratic burden of clearing goods through customs, firms in India also have to deal with corruption in the Indian government. Approximately ninety percent of firms in India make irregular payments to government officials. ${ }^{192}$ This rate is similar to the rates found in Thailand and Indonesia, but is almost twice the rate in Malaysia. ${ }^{193}$ While this imposes additional costs on businesses looking to operate in India, it is not necessarily much of an impediment to them. "If there is little uncertainty regarding the size of the payments and if the payments do secure the desired services, many report that the corruption is not much of a problem."194

\section{FINANCIAL MARKETS}

Another reason foreign businesses are reluctant to invest in India is the number of problems associated with its financial markets. While India has a vibrant financial market with over 9,000 listed companies, ${ }^{195}$ it also has problems, such as high interest expenses, excessive collateral requirements, and burdensome paperwork. ${ }^{196}$ As a result, firms have limited access to expensive loans even though the country has a very high level of savings. ${ }^{197}$ When compared to other firms, Indian firms have a higher percentage of their costs going to interest. For example, in 2002 both China and India were environments of low inflation. India's interest rate on loans was $12.3 \%$, much

189. IMPROVING INVESTMENT CLIMATE, supra note 29. Indian mangers spend about sixteen percent of their time dealing with the government, while in China it is close to nine percent; in Latin America, it is about eleven percent, and in transitional Europe it is about twelve percent. This represents a relative weakness for India, as the opportunity cost for mangers' time is quite high. Id.

190. Id. In India, the longest delay for a typical business was twenty-one days, while in China it was only twelve days. Id.

191. Id.

192. Id.

193. Id.

194. IMPROVING INVESTMENT Climate, supra note 29. The frequency of payments (i.e., bribes) to Indian officials is seen as less of a burden than the time spent dealing with government regulators and agencies. Id.

195. Indian Inv. Ctr., supra note 9.

196. IMPROVING INVESTMENT ClIMATE, supra note 29.

197. Id. 
higher than China's at $5.9 \%{ }^{198}$

\section{LABOR REGULATIONS}

One of the greatest challenges of doing business in India is the restrictions on hiring and firing workers. As reported by a reputable international news source, "India has rigid labour laws that make it almost impossible to fire an employee or hire contract labour. That is one reason India attracts roughly a tenth as much foreign direct investment as China." 199 For a firm to be competitive, it has to be able to allocate its resources, including its workforce, in the most efficient way. This is essential for a firm to realize the benefits of greater competition and openness. The restrictions imposed on firms doing business in India regulating the hiring and firing of workers has resulted in the reluctance of firms to take on new employees. In fact, the typical firm in India has reported that it employs seventeen percent more workers than it desires, and that it is unable to adjust to the optimal level of workforce because of the Indian labor regulations. ${ }^{200}$ As a result, in this critical area India ranks seventy-third out of seventy-five countries in global competitiveness, a staggering position when compared to China at twenty-third. ${ }^{201}$

In addition to the added expense of employing more workers than necessary, Indian companies also face more costs than China as a result of higher wages and reduced productivity. While Indian wages are low compared to developed countries, in fact they are one of the main reasons companies outsource labor there, China's manufacturing wages are even lower. ${ }^{202}$ Chinese workers also offer higher productivity in consumer goods than Indians. It is estimated that an average Indian worker produces at about one-quarter of the efficiency of that of an average Chinese worker. ${ }^{203}$ The enormity of such a statistic is hard to disregard.

\section{COMPARISON TO CHINA}

China and India, the two dominant powers in mainland Asia, have many similarities. They both have common advantages, such as diverse populations of over one billion people and seemingly limitless economic potential. Both China and India also made the transformation from being hostile to FDI in the 1970 s to now encouraging it. The countries also share many problems, such as

198. Id.

199. James Kynge \& Edward Luce, India Starts to See China as a Land of Business Opportunity, FINANCIAL TIMES, Sept. 23, 2003.

200. IMPROVING INVESTMENT CLIMATE, supra note 29.

201. Id.

202. Kynge \& Luce, supra note 199.

203. Id. The consulting firm McKinsey published a recent report stating that on average an Indian worker produces about three shoes per day, while a Chinese worker produces about eleven per day. There was similar productivity dispersion for textiles and ceiling fans. Id. 
mass poverty, oppressive bureaucracies, and widespread corruption. ${ }^{204}$ Yet, despite their many similarities, China has transformed into a super-magnet for FDI while India lags significantly behind. ${ }^{205}$ In the words of one financial writer, "While the sleeping giant that was China has woken with a vengeance, India still appears to be quietly dozing in the corner." ${ }^{206}$ In sum, although both countries now see FDI as an important aspect of economic growth, they face different challenges in realizing this goal.

India started its open door policy later than China, which adopted its open door policy in $1979 .^{207}$ As a result, China has been the largest developing host country of FDI and the second largest country overall ranking, only behind the United States for the last few years. ${ }^{208}$ India, on the other hand, has an FDI total that is less than one-tenth of that of China. ${ }^{209}$ While India started a decade later than China, when it decided to amend its laws, India chose to liberalize much more quickly. China, of course, opened its policy with the typical characteristic of caution. ${ }^{210}$ One other reason for the difference between Indian and Chinese investment levels may very well be the laws and regulations that China has drafted to specifically attract foreign investment. One example of this is the offering of super-national treatment to foreign firms, giving benefits that are not even offered to Chinese domestic firms. ${ }^{211}$ India has not offered comparable super-national tax treatment as of yet.

In addition to the above differences in regulatory policy, there are other possible explanations for the disparity between Indian and Chinese FDI inflows, such as the unusual composition of source countries sending foreign investment to China. The United States, Japan, Germany, France and the United Kingdom were the world's five most important source countries in terms of FDI outflow during the period of 1990 to 1995, according to the United Nations. ${ }^{212}$ In fact, collectively they accounted for seventy percent of all

204. See John Thomhill, China's Challenge, Financial Times, Apr. 12, 2002 (assessing whether Beijing's success will force it to embrace economic reform).

205. WEI, supra note 135.

206. Thornhill, supra note 204.

207. WEI, supra note 135 at 6. "Under Deng Xiaoping, the promulgation of the 1979 'Law on Chinese-foreign equity joint ventures' together with the establishment of four special economic zones formally signaled the adoption of the 'open-door' policy by the central government." Id.

208. Id. at 2.

209. Id.

210. Id. at 6-7. China first allowed only equity joint-ventures or contractual joint ventures, and foreign exchange was tightly regulated. The Chinese government did not allow any whollyowned foreign firms. There was also a tight export performance requirement, sometimes up to $100 \%$. However, these restrictions have been relaxed over time, and now the annual inflow to establish a wholly-owned firm is greater that the inflows for a contractual joint venture, and is close to that of an equity joint venture. $I d$.

211. Id. at 7. For example, foreign firms may receive an income tax exemption for the first two profitable years, followed by a fifty percent tax reduction for three additional years. Id.

212. Thornhill, supra note 204 , at 8 . Since the major source countries avoid corruption and regulatory burdens, many invest heavily in Hong Kong as a stepping stone to investing in 
FDI coming from developed countries. ${ }^{213}$ Hong Kong, however, is the dominant source of FDI in China, accounting for at least half of the total FDI into China for every year between 1992 and $1997 .^{214}$ The United States and Japan were typically the second and third largest investors in China, but they invested less than twenty-five percent of the Hong Kong investment. ${ }^{215}$ Therefore, if one excludes the "false-foreign" and "quasi-foreign" direct investment, the true foreign direct investment would be about fifty percent of what is reported. ${ }^{216}$

One other reason for the difference in FDI in India versus that in China is that the Chinese data may be overstated. For example, in 1996 and 1997, the Chinese source claims to have received investment from the United States in the amount of USD 3.4 billion and 3.2 billion respectively. The United States' source, however, reported only USD 0.9 billion and 1.2 billion respectively. ${ }^{217}$ This data may be overstated due to the government's incentive to exaggerate China's ability to attract FDI, but there may be other reasons as well. ${ }^{218}$ Either way, the investment from Hong Kong and over-reporting of Chinese inflows exacerbate the theoretical discrepancy between foreign investment in India versus that of China.

In the manufacturing sector, China has outperformed India; Chinesemade televisions, air conditioners and cellular phones appear in stores

Mainland China. This may increase the amount of investment in China, as Hong Kong may invest in China on behalf of the major source countries. Id.

213. Id.

214. Id.

One may question whether Hong Kong's investment in Mainland China should be counted as foreign direct investment. This is particularly so since July 1 , 1997, Britain has formally turned over the territory back to China. In that connection, one can at most treat investment coming from Hong Kong as quasiforeign.

Id. Also, part of the Hong Kong investment may include investment from Taiwan, which is disguised to avoid political inconvenience with the Taiwanese government. This part of the Hong Kong investment should also be treated as quasi-foreign investment. Id. at 8-9.

215. Id. at 8 .

216. Id. at 9. "False-foreign" investment includes "round-tripping," a term explaining part of the FDI from Hong Kong, which is actually capital that originates in Mainland China and comes back to Mainland China disguised as Hong Kong investment in order to take advantage of tax, tariff, and other benefits granted to foreign-invested firms. Id.

217. Shang-Jin Wei, Center for RESEARCh on ECONOMiC Development and Policy REFORM, WORKING PAPER NO. 85 SIZING UP FOREIGN DIRECT INVESTMENT IN CHINA AND INDIA 10 (1998), http://scid.stanford.edu/pdf/credpr85.pdf (last visited Mar. 31, 2005); see also WEI, supra note 135. "Generally speaking, the Chinese-reported inflows were much greater that the source countries' own reporting for FDI from the United Kingdom, France, Australia, and Italy as well." Thomhill, supra note 204, at 11 . German and Japanese reported numbers were similar to the Chinese reports. Id. However, Japan reports approval values, which are generally higher than actual values, and German firms are only required to report their investment levels if they hold more than twenty percent of the voting rights or shares in a foreign enterprise. Thus, there is a possibility that the investment from these two firms may still be overstated in Chinese reports. Id.

218. Id. at 11 . For example, the OECD benchmark may be understated, due to items such as reinvested dividends not being properly counted. Id. 
worldwide and goods made in India are rarely seen on the market. ${ }^{219}$ While India offers a massive internal consumer market, it is secondary to China. As a result, Chinese companies have economies of scale larger than their Indian competition. Regardless of the industry, China's market is about three to four times the size of India's. ${ }^{220}$ According to observers, "Whether it is China's cheaper, more reliable power supply, its higher rate of literacy, or the more rapid turnaround at its ports, China remains an incalculably better environment for most manufacturing than India, which is slowly waking up to this."221

Even the advantages India has in the service sector, due to the vast amounts of business-process outsourcing, have started declining, giving China the opportunity to overcome India's gains here as well. China's government has been investing heavily in the human capital needed for the country to develop its own software industry. While China does not boast the vast English-speaking community that India does, it has a steady stream of new graduates who not only speak English, but excel in other Asian languages, such as Japanese and Korean. ${ }^{222}$ Also, as Indian wages are starting to increase, outsourcers are looking to more affordable options like China. ${ }^{223}$ Even though India still holds the advantage in software development and white-collar outsourcing, it is not unreasonable to imagine China as closing in on India's power. It is estimated that India has only a few years to improve its investment climate if it is to maintain its lead in this industry. ${ }^{224}$

Oddly enough, many feel that China offers a more politically stable environment than India. ${ }^{225}$ "China offers the sort of quiet stability that India with open hostility toward Pakistan sparking nuclear-war threats every few years - doesn't."226 It has been suggested that India is too democratic to succeed, while China's autocratic methods have proved effective in enforcing labor discipline, implementing industrial policies, and directing capital into

219. Bruce Einhorn, The Quest for Asia's Outsourcing Crown, BUSINESSWEEK ONLINE, July 30, 2003, at http://netscape.businessweek.com/technology/content/jul2003/tc20030730_ 9305_tc058.htm (last visited Mar. 23, 2005).

$2 \overline{2} 0$. Kynge \& Luce, supra note 199. However, in areas of manufacturing that require high technology inputs, India has the advantage and has even been exporting these goods to China. For example, one auto components manufacturer, based just north of Mumbai, exported about forty million dollars worth of car parts to China in 2002. Id. The CEO of the company said that they have the advantage over their competition in China because their manufacturing is very technical and they have an easier time hiring technologists and engineering graduates than companies in China. Id.

221. Id.

222. Einhorn, supra note 219.

223. Id.

224. See id.

225. Id. Even though China is the last surviving communist power and India is the largest democracy in the world, many see India as a less stable economy. Id. Even more strange is that this is true despite that China has unelected officials who tried to cover up the SARS outbreak up until it became a worldwide crisis. India, on the other hand, has an open economy and free press, making access to information easy. Id.

226. Id. 
export-oriented industries. ${ }^{227}$ With businesses intending to remain in the country for at least ten to twenty years, executives look for a very stable environment to minimize political risk. ${ }^{228}$

Despite the aforementioned advantages, some have characterized both countries as underachievers in foreign investment. Both countries started with an extraordinarily low level of FDI before changes in government policy welcomed FDI. As a result, while China may be seen as a super-magnet for FDI in annual flows, its stock of FDI still has not reached its potential. ${ }^{229}$ The gap between actual inflows and potential inflows is larger for India than for China, but both countries are considered underperformers, even if one only looks at the inflows. ${ }^{230}$ Indeed, corruption and regulatory burdens remain a major deterrent on inflows of FDI in both countries. So while China is seen as an attractive destination for FDI, its absolute values are apparently overstated and remain low compared to its potential. ${ }^{231}$ Thus, in the competition for the foreign dollar, India should recognize that China is formidable, but at the same time vulnerable, to strong competition.

\section{RECOMMENDATIONS TO ACCELERATE THE RATE OF FOREIGN INVESTMENT IN INDIA}

While India has made remarkable progress in improving their investment climate, the country still faces many challenges in achieving its potential. As previously stated, the country's economic growth may be slowing and many Indians still live in poverty. ${ }^{232}$ As Mark Baird, lead author of the World Bank

227. Thornhill, supra note 204. A study completed by the Asian Development Bank Institute (ADBI) suggests that the authoritarian methods used by most east Asian governments were part of the reason for east Asia's economic miracles between the 1960s and 1980s. Id. The current Chinese government has resorted to similar policies in developing its economy, and many feel that a more democratic approach would have prevented China from acceding into the World Trade Organization. Id. While it is not suggested that India abandon its democratic philosophy, indeed democracy is seen as one of the country's greatest achievements by many, it is suggested that India be more flexible and broaden its economic freedoms. Decisions can be made much more quickly in China than in India because there is no need to negotiate or consult. This, along with the competitive populism of Indian states and political parties, hinders an effective national economic policy. Id.

228. Id.

229. WEI, supra note 135 , at 17.

230. Id.

231. Thornhill, supra note 204. Also, many Indian economists suggest that India should not follow any of the models that China uses. Id. They argue that the overstated economic growth rate, the unacceptable and coercive treatment of minority groups, and its unsustainable political system will ultimately result in its economy crashing. The economists further suggest that when the economy does crater, China will be forced to open its political system and follow India's democratic path. Id.

232. Press Release, The World Bank Group, India has Made Impressive Progress, But Faces Major Challenges to Sustain the Trend, says World Bank Development Policy Review (July 19, 2003), at http://www.worldbank.org.in/WBSITE/EXTERNAL/COUNTRIES/ SOUTHASIAEXT/INDIAEXTN/0,,contentMDK:20120511 1 menuPK:295603 pagePK:141137 
Development Policy Review, said:

At current trends, India's rate of progress is insufficient to meet its own Tenth Plan targets as well as the international community's Millennium Development Goals. To achieve its planned growth target of $8 \%$, India will need to impart a fresh impetus to reform. Fiscal adjustment, along with other reforms to improve the investment climate, will be essential to accelerate growth. This will be good for the poor, who also need better access to quality services. These challenges are especially great in the poorer states, which have lagged behind progress at the national level. ${ }^{233}$

One of the main problems lies in the country's political governance, or lack thereof. Therefore, the best way India can increase the level of foreign investment would be to improve the quality of such investment throughout the country. ${ }^{234}$ As major source countries are deterred from investing in corrupt and burdensome countries such as India, many opportunities for attracting FDI are lost. In fact, high corruption and burdensome regulations are generally seen as discouraging far more foreign investment than generous tax incentives and other benefits attract. ${ }^{235}$ For example, it is estimated that if India reduced its corruption rating down to that of Singapore, it could achieve a $348 \%$ increase in foreign investment. ${ }^{236}$ As stated before, the regulatory and administrative burden on firms in India is also a major impediment to growth and investment. Many countries regulate for legitimate and important governmental purposes,

$\sim$ piPK:141127 theSitePK:295584,00.html (last visited Mar. 23, 2005). India's annual economic growth fell from and average of $6.7 \%$ between $1992-93$ and $1996-97$ to $5.5 \%$ between 1997-98 and 2001-02, and further to $4.4 \%$ in 2002-03. Id.

233. Id.

234. Cent. Intelligence Agency, The World FactBook: India, available at http://www.cia.gov/cia/publications/factbook/geos/in.html (n.d.) (last modified Feb. 10, 2005). India's government takes the form of a federal republic, with twenty-eight states and seven union territories. Id. It is led by a president and vice president, elected every five years and a prime minister, elected by parliamentary members of the majority party following legislative elections. India's legal system is based on English common law; it has limited judicial review of legislative acts, and it accepts compulsory ICJ jurisdiction, with reservations. Id. While English is the most important language for national, political, and commercial communication, Hindi is the national language and primary tongue of thirty percent of the people. There are fourteen other official languages spoken in India: Bengali, Telugu, Marathi, Tamil, Urdu, Gujarati, Malayalam, Kannada, Oriya, Punjabi, Assamese, Kashmiri, Sindhi, and Sanskrit; Hindustani is a popular variant of Hindi/Urdu spoken widely throughout northern India but is not an official language. $I d$.

235. WEI, supra note 135 , at 3 .

236. Id. The corruption measure used was conducted by the World Economic Forum in 1996 for its Global Competitiveness Report of 1997. Id. at 3. It is a perception index based on a survey of 2,827 firms in fifty-eight countries. Singapore has a corruption rating of 1.6 on a scale of 1 to 7, while India has a rating of 5.1. Id. 
"but in India the issues are more the extent and nature of regulation, its effectiveness and transparency, and the opportunities for harassment and corruption it provides.",237

Another priority identified in improving investment is reforming the labor market. Restrictions on hiring and firing workers have been considered one of the greatest challenges to doing business in India. ${ }^{238}$ By repealing legislation that prohibits lay-offs in medium and large firms, and changing the regulations that place constraints on the hiring of contract laborers, India could improve industrial performance and attract more private investment. ${ }^{239}$ In addition to reforming the labor market, India should focus on improving the literacy rate. While they have made substantial progress over the last decade, especially with the female population, India still lags behind other Asian countries in education and health indicators. ${ }^{240}$ As discussed throughout this paper, India has a large population of highly-skilled technical workers. However, that is counterbalanced by a very large uneducated, poorer population. "A successful, self-sustaining development process can be based only on the achievements of the individuals who comprise Indian society in all its dimensions."241 By better educating their poor, India empowers them to participate in the growth of their economy, which in turn can increase productivity. ${ }^{242}$

India should also address their high real interest rates, which are also cited as an impediment to business performance and investing in the country. Further, credit has been expensive and time-consuming, if not impossible, to access, which restricts the development of companies. ${ }^{243}$ The interest cost to Indian companies is about $5.5 \%$ of sales, compared to about four percent in most other Asian countries. ${ }^{244}$ While there has been a recent decline in interest

237. See generally Stem, supra note 14. The World Bank has identified several other priorities that can be generally addressed to improve business performance, competitiveness, growth and prosperity in any country. Id. The first priority is industrial deregulation. This includes eliminating preferences and investment ceilings for small scale companies that result in these companies not being able to grow and compete in global markets. This also entails further easing constraints on foreign investment, such as increasing the equity percentages and the number of industries available for automatic approval. Further, opening the economy will allow firms and consumers to take advantage of increased integration into the global economy, and allow the country to maintain a stable macroeconomic environment. To maintain this stability, central and state governments need to raise revenues to control the accumulating fiscal and quasi-fiscal pressures. The regulatory procedures should be streamlined to provide clarity and transparency for investors. Finally, the deregulation includes revamping the bankruptcy legislation. Id.

238. Id. The labor legislation is designed to protect the organized work force, but this sector accounts for only seven percent of the total workforce.

239. See id. at 11.

240. Id. at 14. China, Indonesia, and Sri Lanka all have higher literacy rates than India. Id.

241. Stern Abstract, supra note 145.

242. Stern, supra note 14 , at 14.

243. Carter, supra note 27.

244. Thornhill, supra note 204. These higher interest rates are a result of the country's high fiscal deficits and the high interest rates that India sets on savings accounts. Id. 
rates, so far this has only benefited large, creditworthy borrowers and continues to evade the majority of companies. ${ }^{245}$ It has been suggested that banks should make efforts to introduce new technologies and train branch managers to provide loans to commercially promising debtors. ${ }^{246}$

India also needs to improve its infrastructure, such as improving its power supply, telecommunications, transport, and water supply in additional areas other than special economic zones. ${ }^{247}$ Power supply is considered one of the strongest bottlenecks to investment and growth in India, and it is critical for this sector to be reformed for investment to grow. ${ }^{248}$ In fact, due to the steep costs and unreliability of power supply, about $70 \%$ of companies have been forced to buy their own generators. ${ }^{249}$ The states will need to take action for this reform, rather than the central government, because they are the main providers of infrastructure in India. ${ }^{250}$ As the focus of reform has been increasingly shifted away from the central government in this area, the states should try to create an environment that facilitates private investment to replace the scarce public capital. "While some progress has been made, India's demands for infrastructure services are still not being met. If the private sector is to play a big role in meeting India's infrastructure demands, then Indian needs sectoral policies and a regulatory framework that are conducive to private investment."251 Also recommended is boosting agricultural and rural development. The agricultural sector is in dire need of reform, as it is critical to rural poverty reduction, in the areas of foodgrain policy, subsidies, domestic trade, and land access. According to Michael Carter, the World Bank's Country Director for India:

India has undoubtedly done well in the last two decades, but with one-third of the world's poor and a billion people, it needs rapid growth and job creation to reduce poverty further and sustain the recent income increases. In the absence of comprehensive reform, growth will at best be moderate. India

245. Carter, supra note 27.

246. Id.

247. Stern, supra note 14 , at 12 . See generally Thornhill, supra note 204 . India's transport services deter many investors because their high cost and inefficiency hinders domestic manufacturers. China's distribution and port system is much more efficient than India's, and results in Chinese manufacturers paying thirty-seven percent less than Indian manufacturers pay for shipping goods to the United States. Id.

248. Stern, supra note 14, at 12.

249. Thornhill, supra note 204.

250. Stern, supra note 14 , at 12.

251. World Bank Group, Needed: Private Investment in India's Infrastructure Creating the Right Environment for Investors, at http://wbln1018.worldbank.org/sar/sa.nsf/0/927b3a7c 48d9f4e18525686b0056d7a0?OpenDocument (n.d.) (last visited Mar. 23, 2005) (quoting Edwin Lim's address at the Conference on Distribution Reform (Oct. 12-13, 2001)). 
is a country with huge potential, and a new round of reform could accelerate growth to [eight] percent by the end of the Tenth Plan. ${ }^{252}$

It has also been suggested that one reason India has not achieved its potential, particularly in comparison to China, is because it lacks national ambition. ${ }^{253}$ This could be a result of post-independence India attaching such an importance to economic self-reliance, as well as the country consciously advocating a Hindu versus Western view of economic success. ${ }^{254}$ Some allege that there is a conservative attitude running throughout the leadership of the country, as many government representatives believe that India can achieve only a five percent rate of growth, while most economists suggest that it has the potential to grow at a ten percent rate. ${ }^{255}$ Many Indians are frustrated with the amount of time the reform policy is taking. They feel that when politicians talk about the need for a carefully orchestrated reform process, they are making excuses for doing nothing. For India to achieve its realistic rate of growth, the government needs to develop policies which accurately reflect its potential and take action on those policies. Until then, the sleeping giant will continue to exist in a somewhat somnolent state!

252. WORLD BANK, NEW REPORT SUGgESTS HOW GOVERNMENTS AND CITIZENS MIGHT DO BETTER, in NEWS AND VIEWS QUARTERLY, Oct. 3, 2003, http://siteresources.worldbank.org/ INTINDIA/Newsletters/20192927/OctNews.pdf (last visited Mar. 23, 2005).

253. Thornhill, supra note 204. This is the view of Tarun Das, the director-general of the Confederation of Indian Industry. Id.

254. Id.

255. Id. 